\title{
Ozone production in remote oceanic and industrial areas derived from ship based measurements of peroxy radicals during TexAQS 2006
}

\author{
R. Sommariva ${ }^{1,2, *}$, S. S. Brown ${ }^{1}$, J. M. Roberts ${ }^{1}$, D. M. Brookes ${ }^{3, * *}$, A. E. Parker ${ }^{3, * * *}$, P. S. Monks ${ }^{3}$, T. S. Bates ${ }^{4}$, \\ D. Bon ${ }^{1,2}$, J. A. de Gouw ${ }^{1,2}$, G. J. Frost ${ }^{1,2}$, J. B. Gilman ${ }^{1,2}$, P. D. Goldan ${ }^{1,2}$, S. C. Herndon ${ }^{5}$, W. C. Kuster ${ }^{1,2}$, \\ B. M. Lerner ${ }^{1,2}$, H. D. Osthoff ${ }^{1,2, * * * *}$, S. C. Tucker ${ }^{1,2, * * * * *}$, C. Warneke ${ }^{1,2}$, E. J. Williams ${ }^{1,2}$, and M. S. Zahniser ${ }^{5}$ \\ ${ }^{1}$ Earth System Research Laboratory, NOAA, Boulder, CO, USA \\ ${ }^{2}$ CIRES, University of Colorado, Boulder, CO, USA \\ ${ }^{3}$ Department of Chemistry, University of Leicester, Leicester, UK \\ ${ }^{4}$ Pacific Marine Environmental Laboratory, NOAA, Seattle, WA, USA \\ ${ }^{5}$ Aerodyne Research, Inc., Billerica, MA, USA \\ *now at: School of Environmental Sciences, University of East Anglia, Norwich, UK \\ ** now at: Air Quality Practice, AEA plc., Harwell, Didcot, UK \\ **** now at: PC2A, Université des Sciences et Technologies de Lille, Lille, France \\ ***** now at: Department of Chemistry, University of Calgary, Calgary, Canada \\ ***** now at: Ball Aerospace \& Technologies Corp., Boulder, CO, USA
}

Received: 15 September 2010 - Published in Atmos. Chem. Phys. Discuss.: 7 October 2010

Revised: 23 February 2011 - Accepted: 14 March 2011 - Published: 16 March 2011

\begin{abstract}
During the Texas Air Quality Study II (TexAQS 2006) campaign, a PEroxy Radical Chemical Amplifier (PERCA) was deployed on the NOAA research vessel $\mathrm{R} / \mathrm{V}$ Brown to measure total peroxy radicals $\left(\mathrm{HO}_{2}+\Sigma \mathrm{RO}_{2}\right)$. Day-time mixing ratios of $\mathrm{HO}_{2}+\Sigma \mathrm{RO}_{2}$ between 25 and 110 ppt were observed throughout the study area - the Houston/Galveston region and the Gulf coast of the US - and analyzed in relation to measurements of nitrogen oxides, volatile organic compounds (VOC) and photolysis rates to assess radical sources and sinks in the region.
\end{abstract}

The measurements of $\mathrm{HO}_{2}+\Sigma \mathrm{RO}_{2}$ were used to calculate the in-situ net photochemical formation of ozone. Measured median values ranged from $0.6 \mathrm{ppb} / \mathrm{h}$ in clean oceanic air masses up to several tens of $\mathrm{ppb} / \mathrm{h}$ in the most polluted industrial areas. The results are consistent with previous studies and generally agree with observations made during the previous TexAQS 2000 field campaign. The net photochemical ozone formation rates determined at Barbours Cut, a site immediately south of the Houston Ship Channel, were analyzed in relation to local wind direction and VOC reactivity

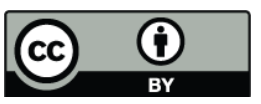

Correspondence to: R. Sommariva (r.sommariva@uea.ac.uk) to understand the relationship between ozone formation and local VOC emissions.

The measurements of $\mathrm{HO}_{2}+\Sigma \mathrm{RO}_{2}$ made during the $\mathrm{R} / \mathrm{V}$ Brown TexAQS 2006 cruise indicate that ozone formation is $\mathrm{NO}_{\mathrm{x}}$-limited in the Houston/Galveston region and influenced by highly reactive hydrocarbons, especially alkenes from urban and industrial sources and their photo-oxidation products, such as formaldehyde.

\section{Introduction}

Peroxy radicals $\left(\mathrm{HO}_{2}\right.$ and $\left.\mathrm{RO}_{2}\right)$ are crucial intermediates in the photochemical formation of ozone $\left(\mathrm{O}_{3}\right)$ in the lower atmosphere because they drive the conversion between $\mathrm{NO}$ and $\mathrm{NO}_{2}$ that leads to net ozone production (Reactions R1-R4).

$$
\begin{aligned}
& \mathrm{RO}_{2}+\mathrm{NO} \rightarrow \mathrm{RO}+\mathrm{NO}_{2} \\
& \mathrm{NO}_{2}+h v \rightarrow \mathrm{NO}+\mathrm{O}\left({ }^{3} \mathrm{P}\right) \quad(\lambda<420 \mathrm{~nm}) \\
& \mathrm{O}\left({ }^{3} \mathrm{P}\right)+\mathrm{O}_{2}(+\mathrm{M}) \rightarrow \mathrm{O}_{3}(+\mathrm{M}) \\
& \mathrm{NO}+\mathrm{O}_{3} \rightarrow \mathrm{NO}_{2}+\mathrm{O}_{2}
\end{aligned}
$$

Published by Copernicus Publications on behalf of the European Geosciences Union. 


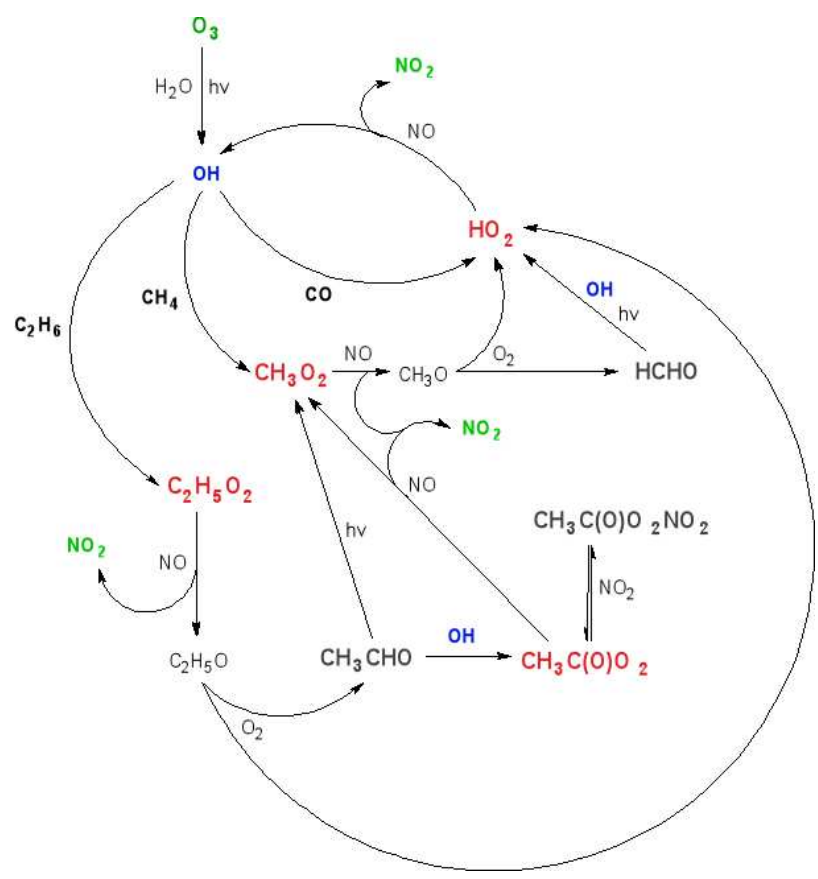

Fig. 1. $\mathrm{CO}, \mathrm{CH}_{4}$ and $\mathrm{VOC}$ (ethane shown as an example) chemistry at high $\mathrm{NO}_{\mathrm{x}}$.

Peroxy radicals are formed from the oxidation of carbon monoxide (CO) and a wide range of Volatile Organic Compounds (VOC). Oxidation of VOC is initiated in the troposphere by free radicals $\left(\mathrm{OH}, \mathrm{NO}_{3}, \mathrm{Cl}\right)$ and by ozone (Monks, 2005). Figure 1 illustrates the chemistry of the simplest peroxy radicals $\left(\mathrm{HO}_{2}, \mathrm{CH}_{3} \mathrm{O}_{2}, \mathrm{C}_{2} \mathrm{H}_{5} \mathrm{O}_{2}\right.$ and $\left.\mathrm{CH}_{3} \mathrm{CO}_{3}\right)$ under high $\mathrm{NO}_{\mathrm{x}}$ conditions. At low $\mathrm{NO}_{\mathrm{x}}$, peroxy radicals selfreact and react with $\mathrm{O}_{3}$; the reactions of peroxy radicals, and $\mathrm{HO}_{2}$ in particular, with $\mathrm{O}_{3}$ causes net chemical loss of ozone. Photochemical ozone formation can therefore be described in terms of peroxy radicals and $\mathrm{NO}$ concentrations. The only inorganic peroxy radical is $\mathrm{HO}_{2}$, but there is a very large number of organic peroxy radicals $\left(\mathrm{RO}_{2}\right)$ owing to the variety of VOC emitted in the troposphere by natural and anthropogenic sources.

Total peroxy radical concentrations $\left(\mathrm{HO}_{2}+\Sigma \mathrm{RO}_{2}\right)$ were measured on board the NOAA research ship R/V Brown during a field campaign along the Gulf coast of the United States that took place in summer 2006 as part of the Second Texas Air Quality Study (Parrish et al., 2009). These measurements were then used to characterize the radical sources and sinks, their diurnal variation and the regional photochemistry relevant to ozone formation along the US Gulf Coast.

Measurements of peroxy radicals from a mobile platform such as a ship provide a unique picture of radical chemistry across a wide range of environments. The R/V Brown sampled air from the remote Gulf of Mexico, aged urban pollution advected over water, highly polluted air from indus- trial areas associated with petrochemical facilities along the Gulf Coast and air influenced primarily by emissions from shipping. Measurements of peroxy radicals, in combination with nitrogen oxides, ozone and related compounds can provide a direct measurement of photochemical ozone production rates. These data show the regional variation in ozone production from clean to highly polluted areas and the correlation of these rates with specific pollutant types.

Section 2 describes the TexAQS 2006 cruise of the $\mathrm{R} / \mathrm{V}$ Brown and the instruments deployed during the campaign and used in this work. The measurements of $\mathrm{HO}_{2}+\Sigma \mathrm{RO}_{2}$ are discussed in Sect. 3. In Sect. 4, the photochemical formation of $\mathrm{O}_{3}$ is calculated from $\mathrm{NO}, \mathrm{O}_{3}$, $j\left(\mathrm{O}^{1} \mathrm{D}\right), \mathrm{H}_{2} \mathrm{O}, \mathrm{HO}_{2}+\Sigma \mathrm{RO}_{2}$ measured during the campaign and $\mathrm{OH}, \mathrm{HO}_{2} /\left(\mathrm{HO}_{2}+\Sigma \mathrm{RO}_{2}\right)$ calculated with a Master Chemical Mechanism (MCM) box-model. The results are discussed and qualitatively compared to the calculations of photochemical formation of $\mathrm{O}_{3}$ made during the TexAQS 2000 campaign, near Houston, Texas.

Throughout the paper, times are expressed in Greenwich Mean Time (GMT $=$ local time $+5 \mathrm{~h}$ along the Gulf coast and $\mathrm{GMT}=$ local time $+4 \mathrm{~h}$ along the Atlantic Coast, Fig. 3a).

\section{Experimental}

\subsection{PERCA}

Total peroxy radicals $\left(\mathrm{HO}_{2}+\Sigma \mathrm{RO}_{2}\right)$ were measured on the R/V Brown using a dual-channel PEroxy Radical Chemical Amplification (PERCA) from the University of Leicester, UK. The instrument has been used in several field studies and has been described in detail in previous publications (Monks et al., 1998; Salisbury et al., 2002; Fleming et al., 2006; Green et al., 2006; Parker et al., 2009).

The chemical amplification technique catalytically converts $\mathrm{HO}_{2}$ and $\mathrm{RO}_{2}$ into $\mathrm{CO}_{2}$ and $\mathrm{NO}_{2}$ (Cantrell et al., 1984, 1996b). Organic peroxy radicals are converted into $\mathrm{HO}_{2}$ (Reactions $\mathrm{R} 5-\mathrm{R} 6)$ and $\mathrm{HO}_{2}$ is converted into $\mathrm{OH}$ by reaction with $\mathrm{NO}$ (Reaction R7); by adding $\mathrm{CO}$ to the inlet, $\mathrm{OH}$ is converted back to $\mathrm{HO}_{2}$ (Reaction R8), thus producing multiple $\mathrm{NO}_{2}$ molecules per each $\mathrm{HO}_{2}$ and $\mathrm{RO}_{2}$ radical. $\mathrm{NO}_{2}$ is then measured by luminol chemiluminescence. The amplification cycle is terminated when radicals are removed from the system, by formation of $\mathrm{HONO}, \mathrm{HNO}_{3}, \mathrm{HO}_{2} \mathrm{NO}_{2}$ or by loss on the inlet walls. The number of cycles before termination occurs is the chain length $(C L)$, which is characteristic of the inlet and a measure of the efficiency of the amplification.

$$
\begin{aligned}
& \mathrm{RO}_{2}+\mathrm{NO} \rightarrow \mathrm{RO}+\mathrm{NO}_{2} \\
& \mathrm{RO}+\mathrm{O}_{2} \rightarrow \mathrm{HO}_{2}+\mathrm{RCHO} \\
& \mathrm{HO}_{2}+\mathrm{NO} \rightarrow \mathrm{OH}+\mathrm{NO}_{2} \\
& \mathrm{OH}+\mathrm{CO}+\mathrm{O}_{2}(+\mathrm{M}) \rightarrow \mathrm{HO}_{2}+\mathrm{CO}_{2}(+\mathrm{M})
\end{aligned}
$$


In addition to $\mathrm{NO}_{2}$ formed by peroxy radicals reacting in the inlet, a significant background $\mathrm{NO}_{2}$ signal - due to ambient $\mathrm{NO}_{2}$ and to the reaction between $\mathrm{O}_{3}$ and $\mathrm{NO}$ inside the inlet - is also observed. Consequently, the measurements in the inlet are modulated so that 1 min of amplification of the radical signal is alternated with 1 min of termination of the radical signal. The difference between the amplification and the termination mode signals consists in $\mathrm{NO}_{2}$ formed only by $\mathrm{HO}_{2}$ and $\mathrm{RO}_{2}$ radicals. The PERCA deployed on the R/V Brown had two inlets (dual-channel, Cantrell et al. (1996a); Kartal et al. (2010)), so that when one inlet was in amplification mode the other was in background mode, increasing the time resolution of the measurements to $1 \mathrm{~min}$, compared to 2 min of a single-channel PERCA.

The total concentration of radicals is obtained by dividing the measured concentration of $\mathrm{NO}_{2}$ by the chain length (Eq. 1). Since the concentration of $\mathrm{OH}$ is typically two orders of magnitude lower than the concentration of peroxy radicals, this is equivalent to the sum of $\mathrm{HO}_{2}$ and organic peroxy radicals $\left(\mathrm{RO}_{2}\right)$ :

$$
\left([\mathrm{OH}]+\left[\mathrm{HO}_{2}\right]+\left[\mathrm{RO}_{2}\right]\right)=\frac{\Delta \mathrm{NO}_{2}}{C L}
$$

The PERCA instrument deployed on the R/V Brown used one chemiluminescence detector (Scintrex LMA-3) per inlet to measure $\mathrm{NO}_{2}$. The $\mathrm{NO}_{2}$ detectors were calibrated every day using known concentrations of $\mathrm{NO}_{2}$ from two permeation tubes located next to the inlets (Green et al., 2006).

Calibration of the Scintrex LMA-3 detectors was checked by comparison against a cavity ring-down (CRD) instrument (Osthoff et al., 2006). The two instruments were connected in series, so that $\mathrm{NO}_{2}$ was first measured by the CRD and then by the Scintrex LMA-3. The result of the comparison is shown in Fig. 2. The agreement between the Scintrex LMA3 and the CRD was $\sim 9 \%$, which is within the uncertainties of the two instruments (5\% and $20 \%$, respectively (Osthoff et al., 2006; Fleming, 2005)). The Scintrex LMA-3 overestimated $\mathrm{NO}_{2}$ by $4.5 \mathrm{ppb}$ (Fig. 2); the offset, however, did not affect the peroxy radical measurement, because these are determined from the difference between the two $\mathrm{NO}_{2}$ channels rather than from the absolute $\mathrm{NO}_{2}$ concentration.

The largest uncertainty factor is the determination of the chain length $(C L)$. During the R/V Brown cruise $C L$ was determined approximately every 3-4 days via generation of a known concentration of $\mathrm{CH}_{3} \mathrm{O}_{2}$ radicals from the photolysis of methyl iodide $\left(\mathrm{CH}_{3} \mathrm{I}\right)$ in zero air (Fleming et al., 2006). Typical chain lengths were 100-160 in channel \#1 and 34-45 in channel \#2: the difference in $C L$ was taken into account during the data workup, so the two channels gave the same response to ambient peroxy radicals.

To validate the calibration method, $C L$ was also determined using $\mathrm{CH}_{3} \mathrm{C}(\mathrm{O}) \mathrm{O}_{2}$ radicals. The calibration source of a Chemical Ionization Mass Spectrometer (CIMS, Slusher et al., 2004) used to measured PANs on the R/V Brown was

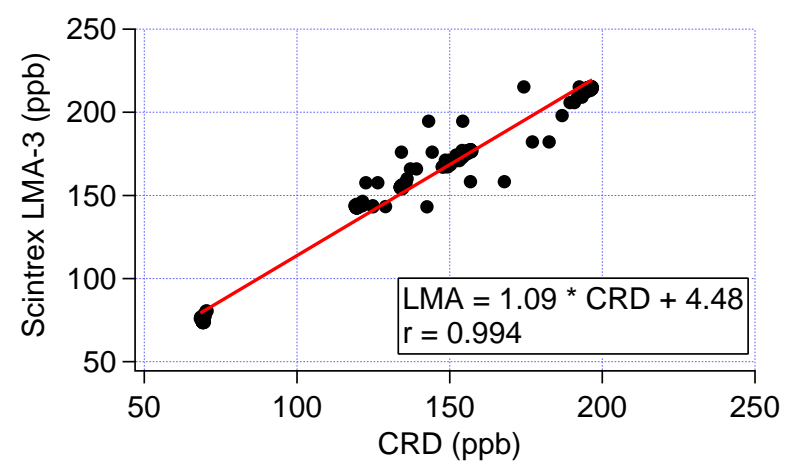

Fig. 2. Comparison between the Scintrex LMA-3 detector and the Cavity Ring-down Spectrometer during an $\mathrm{NO}_{2}$ calibration of the PERCA instrument.

put inside the PERCA inlet and heated to different temperatures to inject different concentrations of acetyl peroxy radicals into the PERCA inlet. $\mathrm{CH}_{3} \mathrm{C}(\mathrm{O}) \mathrm{O}_{2}$ is promptly converted to $\mathrm{CH}_{3} \mathrm{O}_{2}$ by reaction with $\mathrm{NO}$, so the chain lenghts measured with the two radicals are expected to be very close. In fact, the chain lengths determined by the two procedures differed by less than $10 \%$, a difference that is well within the range of the estimated measurement error of the PERCA.

Previous work has shown the PERCA chain length to be dependent on both ambient humidity and temperature (Salisbury et al., 2002; Reichert et al., 2003). Therefore, it is usually determined in dry air and then corrected using a calibration factor. However, the determination of $C L$ during the experiment with the PAN source was carried out in ambient (humid) air. The agreement between the $C L$ determined in ambient air with PAN and the $C L$ determined in zero air with $\mathrm{CH}_{3} \mathrm{I}$ demonstrates that the data collected during the TexAQS 2006 cruise did not require a correction for relative humidity. This was also the case for a similar PERCA instrument during another field campaign under similarly high ambient humidity and temperature conditions (AndrésHernández et al., 2010). Raw data were only corrected for the $\mathrm{RH}$ dependence of the $\mathrm{NO}_{2}$ measurements from the Scintrex LMA-3 detector using a correction factor $(\sim 30 \%)$ determined in the laboratory after the campaign.

Combining the 2- $\sigma$ uncertainties in the measurement of $\mathrm{NO}_{2}$, in the determination of the $C L$ and in the correction factor for the $\mathrm{NO}_{2}$ detector for both channels, the total uncertainty of the instrument during the TexAQS 2006 cruise of the R/V Brown was $40 \%$ with a detection limit of $2 \mathrm{ppt}$ (for $1 \mathrm{~min}$ integration time).

A simple box-model (Sect. 4.1) was run for the clean conditions encountered in air masses from the remote regions of the Gulf of Mexico and the Atlantic Ocean. Under these conditions the chemical cycling is reasonably well understood (Sommariva et al., 2004) and the good agreement between the uncorrected $\mathrm{HO}_{2}+\Sigma \mathrm{RO}_{2}$ data and the box-model results supports the overall accuracy of the PERCA measurements. 


\subsection{Instruments on board the R/V Brown}

A number of other measurements relevant to this work were deployed on the R/V Brown and are described in detail elsewhere (Parrish et al., 2009). $\mathrm{NO}$ and $\mathrm{NO}_{2}$ were measured using a chemiluminescence technique (Ryerson et al., 2000): the detection limits were 0.01 and $0.06 \mathrm{ppb}$ with an uncertainty of $3.8 \%$ and $13 \%$, respectively. CO was measured by UV-fluorescence (detection limit $=1.5 \mathrm{ppb}$ with $3 \%$ uncertainty) and $\mathrm{O}_{3}$ by UV-absorbance (detection limit $=1 \mathrm{ppb}$ with $2 \%$ uncertainty). All these instruments had integration times of 1 min (Parrish et al., 2009).

The photolysis rates of $\mathrm{O}_{3}, \mathrm{NO}_{2}$ and $\mathrm{NO}_{3}$ were measured with filter radiometers (Stark et al., 2007), with uncertainties between $12 \%\left(j\left(\mathrm{NO}_{2}\right)\right)$ and $26 \%\left(j\left(\mathrm{O}_{3}\right)\right)$ and 1 min integration times. ${ }^{222}$ Radon was detected using a dual flow loop two filter detector (Bates et al., 2008), located on the upper deck of the R/V Brown.

Speciated VOC ( 96 total) were measured by a dual channel gas chromatograph system with a flame ionization detector (GC-FID) on one channel and a mass spectrometer (GCMS) on the other. The instrument, which collected $5 \mathrm{~min}$ samples every $25 \mathrm{~min}$, measured the mixing ratios of $\mathrm{C} 2-\mathrm{C} 9$ VOC with a detection limit of $0.5-1 \mathrm{ppt}$, depending on the species, and an uncertainty of $20 \%$ (Gilman et al., 2009). Acetaldehyde and acetic acid were measured by Proton Transfer Ion Trap Mass Spectrometry (PIT-MS), with $<0.5 \mathrm{ppb}$ detection limit and 20\% uncertainty for 1 min integration time (Warneke et al., 2005). $\mathrm{HCHO}$ and $\mathrm{HCOOH}$ were measured by Tunable Infrared Laser Differential Absorption Spectroscopy (TILDAS) with detection limit of $180 \mathrm{ppt}$ and $10 \%$ uncertainty for $1 \mathrm{~s}$ integration time (Herndon et al., 2007).

NOAA's High Resolution Doppler Lidar (HRDL) performed measurements of atmospheric boundary layer wind, aerosol backscatter, and turbulence profiles with a resolution of $15 \mathrm{~min}$ and $30 \mathrm{~m}$ (Tucker et al., 2010). These measurements were used to estimate the mixing height, which determines the dilution of near surface emissions of pollutants by vertical mixing in the boundary layer.

The instruments, including the PERCA, were housed in sea containers mounted on one of the upper decks in the forward part of the R/V Brown, approximately $12 \mathrm{~m}$ above the sea surface. The inlets were located at the top of a $8 \mathrm{~m}$ tower, approximately $20 \mathrm{~m}$ above the sea surface. The HRDL Lidar was located at the stern of the ship.

\subsection{The TexAQS 2006 cruise of the R/V Brown}

The Texas Air Quality Study 2006 campaign took place during the summer of 2006. The campaign was part of the more comprehensive TexAQS/GoMACCS (Gulf of Mexico Atmospheric Composition and Climate Study) regional air quality and climate change study and its main objective was to investigate air quality and meteorology along the Gulf

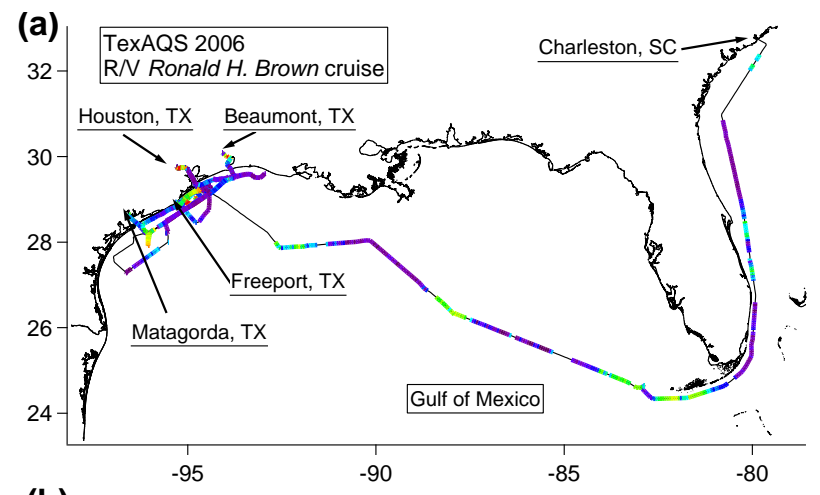

(b)

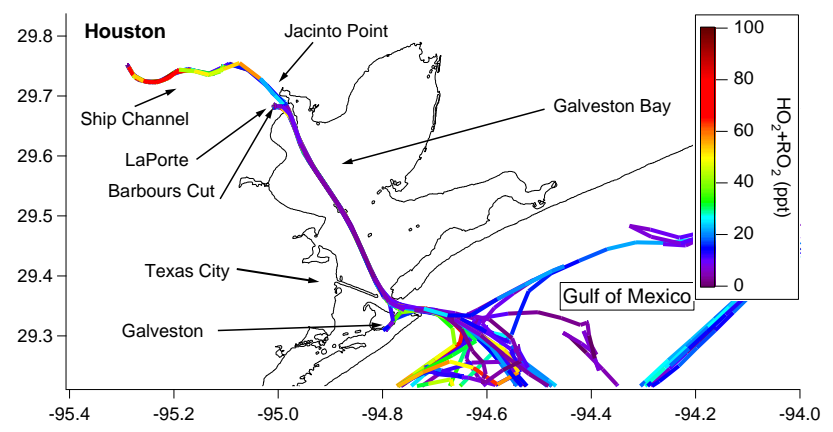

Fig. 3. Map of the Southern United States and the Gulf of Mexico showing the track of the R/V Brown during TexAQS 2006. The ship track is color-coded with $\mathrm{HO}_{2}+\Sigma \mathrm{RO}_{2}$ measurements (in ppt). Note that several transects overlap, especially in the Galveston Bay and in the Houston Ship Channel, and that mixing ratios larger than $100 \mathrm{ppt}$ are not shown.

coast of the United States and in particular around the Houston/Galveston area. The NOAA research vessel R/V Brown sailed from Charleston, South Carolina, on 27 July and arrived in Houston, Texas, on 2 August. Between 2 August and 11 September the R/V Brown cruised along the coast of Texas, inside Galveston Bay and up the Sabine River to Beaumont, Texas. The track of the ship is shown in Fig. 3, which also indicates several of the locations visited during the cruise. Approximately $20 \%$ of the entire research cruise was spent at a single location, Barbours Cut (Fig. 3b), a commercial shipping dock south of the Houston Ship Channel and close to the site (LaPorte, Texas) of a previous field campaign (TexAQS 2000, Ryerson et al., 2003; Jobson et al., 2004).

The Houston/Galveston area is home to one of the busiest ports of the United States. The port opens at Galveston Bay and ends in the Houston Ship Channel (Fig. 3b), which is currently one of the most important waterways for the movement of petrochemical products, goods and grains in North America. The Houston Ship Channel is approximately $160 \mathrm{~m}$ wide and $80 \mathrm{~km}$ long and is entirely surrounded by loading docks and petrochemical industries. The ship traffic between the Houston Ship Channel and the Gulf of Mexico mostly 
consists of tankers, freighters and large number of barges and tugboats. This, together with the rest of the industrial activity and the urban traffic in and around the Greater Houston metropolitan area, results in high emissions of $\mathrm{NO}_{\mathrm{x}}$ and VOC, responsible for the high photochemical activity and formation of ozone in the region (Ryerson et al., 2003; Parrish et al., 2009). The ocean along the coast of Southern Texas is also subject to considerable ship traffic and a large number of oil extraction platforms, mostly located on the continental shelf. Other industrial areas are present all along the coast of Texas: during the 2006 cruise, the R/V Brown sampled in Port Arthur and in Beaumont, near the border with Louisiana, in Freeport and in Matagorda, southwest of Galveston along the Gulf Coast (Fig. 3a).

The local meteorology in the Houston/Galveston region has a profound influence on ozone concentration and radical chemistry. Stagnant conditions over the shores of Galveston Bay can arise when moderate offshore synoptic-scale winds are strong enough to override and suppress the early afternoon bay breeze (Banta et al., 1998, 2005). This allows for accumulation of photochemical ozone over Galveston Bay, which is subsequently advected over Houston in the lowest few hundred meters by the late afternoon on-shore sea breeze. Tucker et al. (2010) also observed the effect of the synoptic conditions on boundary layer mixing height and impact on the concentration of ozone in this area.

Previous studies in the region (e.g. Ryerson et al., 2003; Jobson et al., 2004; Kleinman et al., 2005) have highlighted the special chemical characteristics of the Houston/Galveston area: co-located large emissions of $\mathrm{NO}_{\mathrm{x}}$ and of highly reactive VOC (particularly light alkenes) combined with the unique meteorology described above result in some of the highest concentrations of urban ozone in the United States. Measurements of peroxy radicals in such photochemically active air masses provide a unique look into their chemistry and assists in understanding the factors that influence ozone production across the region.

\section{Measurements of $\mathrm{HO}_{2}+\Sigma \mathrm{RO}_{2}$}

Total peroxy radicals were measured continuously ( $>90 \%$ of data coverage) from 28 July to 11 September on board the R/V Brown during TexAQS 2006. The entire dataset is shown in Fig. 3 and, together with measurements of $\mathrm{O}_{3}$ photolysis rates $\left(j\left(\mathrm{O}^{1} \mathrm{D}\right)\right), \mathrm{NO}_{\mathrm{x}}$ and selected VOC in Fig. 4. The concentrations of total peroxy radicals were clearly correlated with $\mathrm{O}_{3}$ photolysis rates throughout the cruise; this is expected as ozone was always a major radical source, even in the most polluted areas, where $\mathrm{HCHO}$ and $\mathrm{HONO}$ were also important radical sources (Olaguer et al., 2009).

Day-time (08:00-20:00 local time) maximum mixing ratios of $\mathrm{HO}_{2}+\Sigma \mathrm{RO}_{2}$ ranged from 25 to $110 \mathrm{ppt}$. The highest average levels were observed in the industrial areas (Fig. 5), owing to the abundance of VOC, the precursors of peroxy
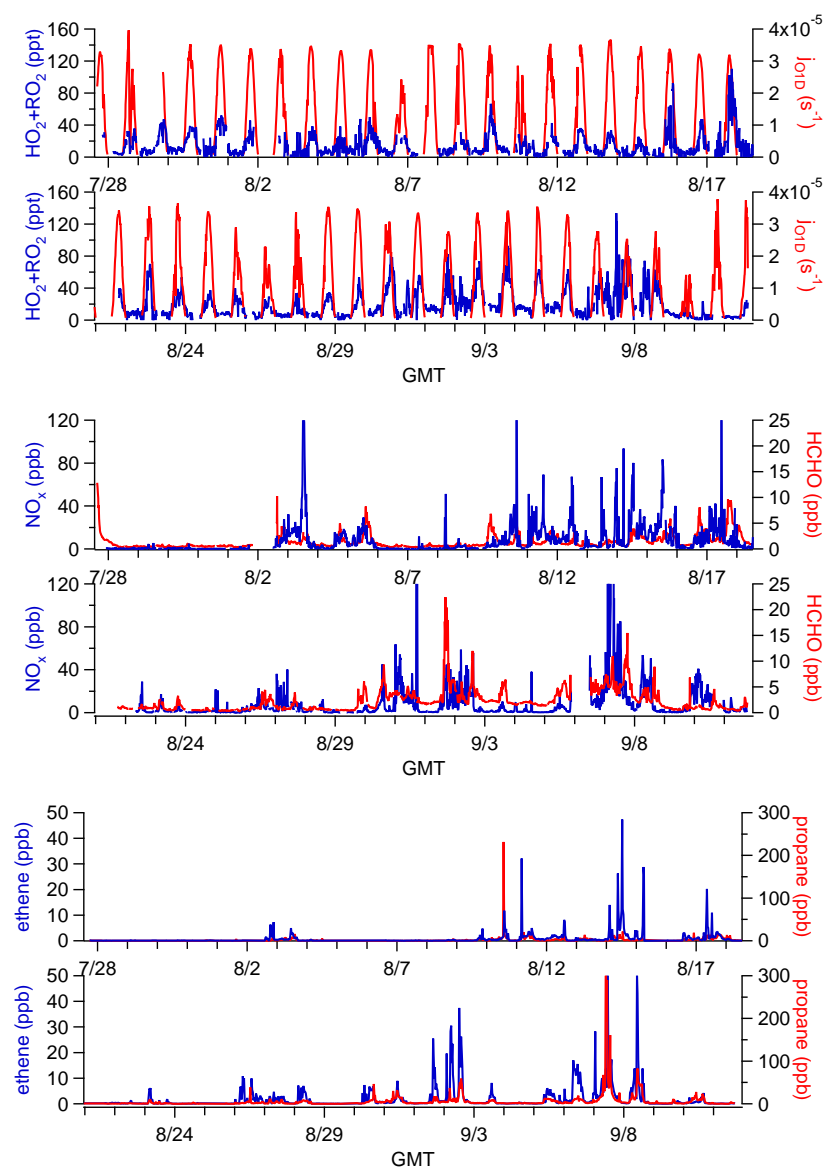

Fig. 4. Measurements of $\mathrm{HO}_{2}+\Sigma \mathrm{RO}_{2}, j\left(\mathrm{O}^{1} \mathrm{D}\right), \mathrm{NO}_{\mathrm{x}}, \mathrm{HCHO}$, ethene and propane during the R/V Brown cruise.

radicals, and of $\mathrm{NO}_{\mathrm{x}}$ (Fig. 1). During the first few days of the cruise (28 July to 2 August) the R/V Brown was en route from Charleston, South Carolina, to Houston, Texas (Fig. 3a), sampling the cleanest air masses of the campaign. Measured day-time peroxy radicals maxima were, on average, between 35 and 50 ppt during this period. Gilman et al. (2009) showed that VOC accounted for approximately $32 \%$ of the total $\mathrm{OH}$ reactivity and the most important VOC were formaldehyde $(0.5 \mathrm{ppb})$, acetaldehyde $(0.1 \mathrm{ppb})$ and light alkenes $(0.01-$ $0.06 \mathrm{ppb}$ ). $\mathrm{CO}$ and $\mathrm{CH}_{4}$ accounted, respectively for $38 \%$ and $27 \%$ of the total $\mathrm{OH}$ reactivity (Gilman et al., 2009); it can be inferred that, during this period, $\mathrm{HO}_{2}+\Sigma \mathrm{RO}_{2}$ was comprised mostly of $\mathrm{HO}_{2}$ and $\mathrm{CH}_{3} \mathrm{O}_{2}$. These measurements in clean marine air $\left(\left[\mathrm{NO}_{\mathrm{x}}\right]=0.2-0.4 \mathrm{ppb}\right.$, on average), originating in the subtropical Atlantic Ocean and the Caribbean region, can be considered representative of background marine conditions.

Peroxy radicals were also measured at night during the entire cruise with mixing ratios typically between 5 and $25 \mathrm{ppt}$, depending on the conditions and the location of the $\mathrm{R} / \mathrm{V}$ Brown. On occasion, very high mixing ratios were measured, such as during the night of 7 September when the 
Table 1. Day-time (08:00-20:00) and night-time averages and standard deviations of $\mathrm{HO}_{2}+\Sigma \mathrm{RO}_{2}$ (in ppt), $\mathrm{NO}_{\mathrm{x}}$ (in ppb) and total OH reactivity of $\operatorname{VOC}\left(1 / \tau_{\mathrm{OH}}\right.$ in $\left.\mathrm{s}^{-1}\right)$ measured at different locations during the $\mathrm{R} / \mathrm{V}$ Brown cruise.

\begin{tabular}{l|ccccc}
\hline Species & Open Ocean & Gulf Coast & Galveston Bay & Industrial Areas & Barbours Cut \\
\hline day & & & & & \\
$\mathrm{HO}_{2}+\Sigma \mathrm{RO}_{2}$ & $20.5 \pm 12.4$ & $30.2 \pm 21.0$ & $25.4 \pm 18.8$ & $27.4 \pm 21.9$ & $14.6 \pm 11.2$ \\
$\mathrm{NO}_{\mathrm{x}}$ & $0.7 \pm 1.8$ & $2.4 \pm 4.0$ & $8.2 \pm 17.7$ & $15.0 \pm 19.5$ & $14.9 \pm 14.9$ \\
$1 / \tau_{\mathrm{OH}}$ & $0.4 \pm 0.2$ & $2.1 \pm 2.5$ & $3.3 \pm 4.0$ & $7.8 \pm 14.0$ & $5.0 \pm 5.7$ \\
\hline night & & & & & \\
$\mathrm{HO}_{2}+\Sigma \mathrm{RO}_{2}$ & $5.6 \pm 3.9$ & $12.6 \pm 4.6$ & $8.7 \pm 7.9$ & $11.7 \pm 18.8$ & $11.7 \pm 13.3$ \\
$\mathrm{NO}_{\mathrm{x}}$ & $1.0 \pm 3.4$ & $1.7 \pm 2.2$ & $13.5 \pm 11.9$ & $60.1 \pm 231.0$ & $14.9 \pm 12.3$ \\
$1 / \tau_{\mathrm{OH}}$ & $0.3 \pm 0.2$ & $1.9 \pm 2.4$ & $2.3 \pm 2.0$ & $13.8 \pm 32.9$ & $9.4 \pm 15.0$ \\
\hline
\end{tabular}
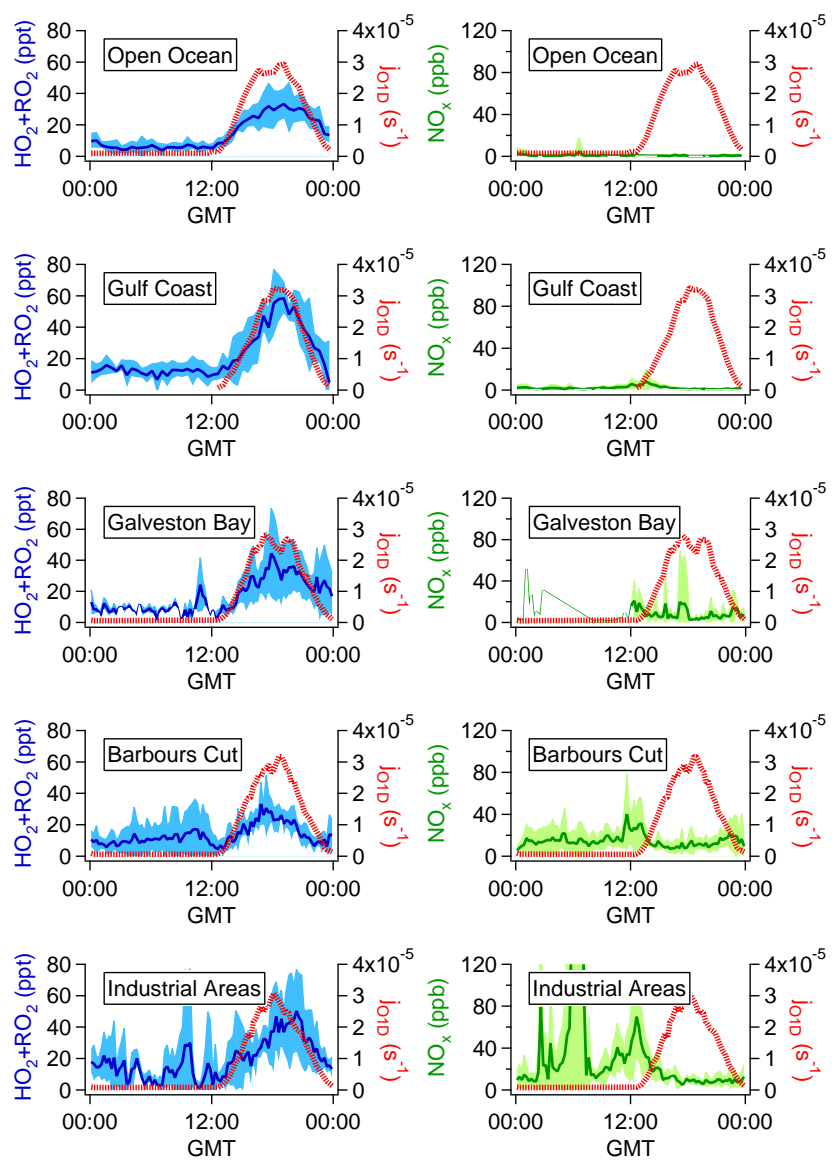

Fig. 5. Average diurnal profiles of $\mathrm{HO}_{2}+\Sigma \mathrm{RO}_{2}$ (in blue), $\mathrm{NO}_{\mathrm{x}}$ (in green) and $j\left(\mathrm{O}^{1} \mathrm{D}\right)$ (in red) at different locations during the $\mathrm{R} / \mathrm{V}$ Brown cruise. The shading corrsponds to $1-\sigma$.

$\mathrm{R} / \mathrm{V}$ Brown was docked in Jacinto Point at the entrance to the Houston Ship Channel (Fig. 3b). On this night, $\mathrm{HO}_{2}+\Sigma \mathrm{RO}_{2}$ reached a campaign maximum of $134 \mathrm{ppt}$, related to nighttime oxidation reaction $\left(\mathrm{O}_{3}\right.$ or $\left.\mathrm{NO}_{3}\right)$ of highly reactive VOC. During this event, the GC-MS sampled a plume, likely emitted from one of the nearby petrochemical plants, largely composed of $\mathrm{C} 2-\mathrm{C} 5$ alkenes with a combined mixing ratio of $190 \mathrm{ppb}$ (Gilman et al., 2009). $\mathrm{NO}_{3}$ measurements for that night were not available. However, during the event, [NO] was about $4 \mathrm{ppb}$, which suggests that ozone reactions with alkenes was responsible for the formation of such high level of peroxy radicals, because $\mathrm{NO}_{3}$ would be titrated by $\mathrm{NO}$ faster than it could react with any other species.

The measurements taken during the $\mathrm{R} / \mathrm{V}$ Brown cruise were divided into 5 groups, defined by the location of the ship. They are referred to hereafter as: Open Ocean, Gulf Coast, Galveston Bay, Industrial Areas and Barbours Cut. Diurnal profiles of the $\mathrm{HO}_{2}+\Sigma \mathrm{RO}_{2}$ and $\mathrm{NO}_{\mathrm{x}}$ measurements at each location are shown in Fig. 5. The diurnal and nocturnal averages and standard deviations of $\mathrm{HO}_{2}+\Sigma \mathrm{RO}_{2}, \mathrm{NO}_{\mathrm{x}}$ and VOC reactivity are shown in Table 1 . The data taken when the ship was in the Atlantic Ocean and in the Gulf of Mexico (Fig. 3a) were divided between the Open Ocean and Gulf Coast groups using ${ }^{222}$ Radon counts. ${ }^{222}$ Radon is a byproduct of the degradation of ${ }^{238}$ Uranium with half-life of 3.82 days; it is commonly released in the atmosphere from granitic soils and rocks and therefore can be used as a tracer of continental influence.

Gulf Coast air masses were rich in ${ }^{222}$ Radon and contained continental outflow and anthropogenic influence, with higher mixing ratios of total peroxy radicals and $\mathrm{NO}_{\mathrm{x}}$ : the day-time maxima of $\mathrm{HO}_{2}+\Sigma \mathrm{RO}_{2}$ were about $60 \mathrm{ppt}$ (diurnal average $=30.2 \mathrm{ppt}$ and average $\mathrm{NO}_{\mathrm{x}}=2.4 \mathrm{ppb}$, respectively, Fig. 5). Open Ocean air masses poor in ${ }^{222}$ Radon were less impacted by recent anthropogenic emissions and had lower mixing ratios of peroxy radicals and $\mathrm{NO}_{\mathrm{x}}$ : the day-time maxima of $\mathrm{HO}_{2}+\Sigma \mathrm{RO}_{2}$ were about 30-35 ppt (diurnal average $=$ $20.5 \mathrm{ppt}$ ) and average $\mathrm{NO}_{\mathrm{x}}=0.7 \mathrm{ppb}$ (Table 1, Fig. 5). The sources of peroxy radicals in these two areas were likewise different: in the Open Ocean they were formed mostly by $\mathrm{CO}$ and $\mathrm{CH}_{4}$, which together accounted for about $65 \%$ of the total $\mathrm{OH}$ reactivity, on average. The role of $\mathrm{VOC}$ in the formation of peroxy radicals was mostly due to the reactivity of oxygenated compounds, especially formaldehyde and acetaldehyde (Gilman et al., 2009). In the Gulf Coast, owing to the outflow of polluted air from the continent, the production 
of peroxy radicals was controlled by VOC, particularly alkanes, alkenes and oxygenates, which accounted for a much larger fraction $(\sim 53 \%$, on average $)$ of the reactivity of $\mathrm{OH}$ (Gilman et al., 2009).

The data grouped under Galveston Bay include all the measurements taken when the ship was in Galveston harbour and in Galveston Bay itself (Fig. 3b). These data were affected especially by shipping emissions and, to a certain extent, by industrial emissions, but not as much as those grouped under Industrial Areas, which were taken close to the emission points (that is the Houston Ship Channel, Freeport, Matagorda and Beaumont, Fig. 3). Day-time peroxy radicals and $\mathrm{NO}_{\mathrm{x}}$ mixing ratios were, on average, around 40-45 ppt (day-time maximum) and $8.2 \mathrm{ppb}$, respectively, in Galveston Bay, while they were about 45-50 ppt (day-time maximum) and $15 \mathrm{ppb}$, respectively, in the Industrial Areas (Table 1, Fig. 5). Measurements in the Industrial Areas showed greater variability than those in other places (Fig. 5), partly because of the smaller number of samples in the diurnal averages, and partly because of the spatial and temporal variability of local, industrial emission sources. The sources of peroxy radicals in these areas were dominated by oxidation of non-methane hydrocarbons, which accounted for $72 \%$ of the reactivity of $\mathrm{OH}$ (Gilman et al., 2009). While C2-C4 alkanes were the most abundant $\mathrm{RO}_{2}$ precursors, the largest fraction of the $\mathrm{OH}$ reactivity was due to light alkenes and formaldehyde (Gilman et al., 2009).

Although the chemical characteristics of the air masses sampled in Barbours Cut (Figs. 3b, 5) were not dissimilar from those measured in the Galveston Bay or in the Industrial Areas (depending on the meteorology), these data were analyzed separately since this was the single location where the ship spent the most time; it is also $\sim 6 \mathrm{~km}$ from the ground site (LaPorte airport) of the TexAQS 2000 field campaign, thus enabling the most direct comparison of radical measurements between the two study years. Day-time mixing ratios of $\mathrm{HO}_{2}+\Sigma \mathrm{RO}_{2}$ in Barbours Cut were about 30-35 ppt (daytime maximum), with about $15 \mathrm{ppb}$ of $\mathrm{NO}_{\mathrm{x}}$ (Fig. 5). Air masses at this location were influenced principally by the neighbouring Houston Ship Channel and Texas City (Fig. 3b) and/or by air masses from Galveston Bay.

Barbours Cut measurements showed a distinctive decrease in $\mathrm{HO}_{2}+\Sigma \mathrm{RO}_{2}$ concentration around 12:00 GMT (07:00 local time), which was also observed, to a lesser extent, in the Industrial and Galveston Bay average diurnal profiles (Fig. 5). This dip in $\mathrm{HO}_{2}+\Sigma \mathrm{RO}_{2}$ was largely related to a corresponding increase in $\mathrm{NO}_{\mathrm{x}}$ when emissions from traffic and industries started to build up, just before sunrise, in the shallow $(\sim 200 \mathrm{~m})$ nocturnal boundary layer (Tucker et al., 2010). The breakup of this shallow layer after sunrise and the subsequent mixing with cleaner air from aloft caused a sharp decrease in $\mathrm{NO}_{\mathrm{x}}, \mathrm{CO}$ and the precursor VOC and an increase in $\mathrm{HO}_{2}+\Sigma \mathrm{RO}_{2}$ concentrations.

Figure 6 shows the medians and the 10-th, 25-th, 75-th and 90-th percentiles of measured $\mathrm{HO}_{2}+\Sigma \mathrm{RO} 2$ concentra-
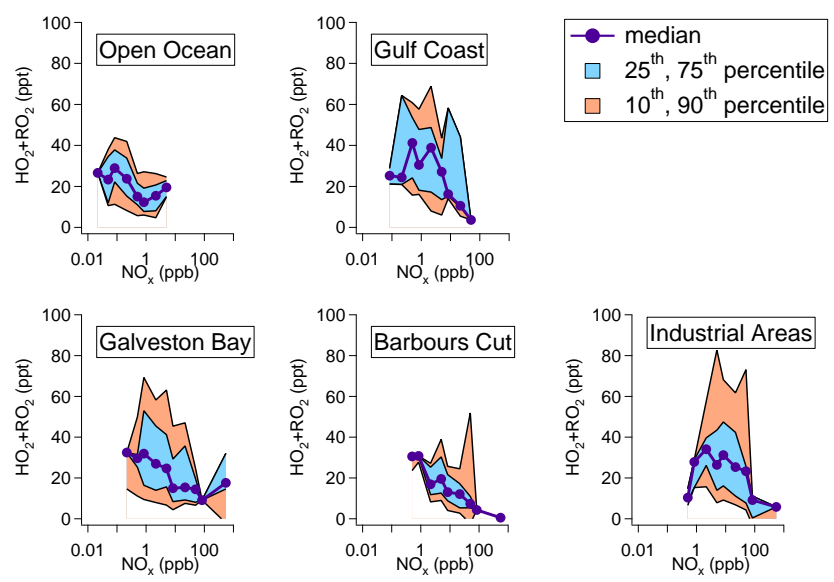

Fig. 6. Day-time measurements of $\mathrm{HO}_{2}+\Sigma \mathrm{RO}_{2}$ vs. $\mathrm{NO}_{\mathrm{x}}$ at different locations during the R/V Brown cruise.

tions plotted versus $\mathrm{NO}_{\mathrm{x}}$ during the day in the different regions. As the ship moved from the Open Ocean to the Gulf Coast and into Galveston Bay (Fig. 6), there was a transition from low to high $\mathrm{NO}_{\mathrm{x}}$. Accordingly, the peroxy radical mixing ratios increased from 10-20 ppt in the clean marine boundary layer to several tens of ppt in the most polluted areas.

The concentrations of $\mathrm{HO}_{2}+\Sigma \mathrm{RO}_{2}$ peaked at intermediate $\left[\mathrm{NO}_{\mathrm{x}}\right]$ and decreased at higher $\left[\mathrm{NO}_{\mathrm{x}}\right]$, but the dependence of $\mathrm{HO}_{2}+\Sigma \mathrm{RO}_{2}$ on nitrogen oxides is not always clear because of the high variability of the measurements in the polluted areas (like Barbours Cut and the Industrial Areas) compared to the clean Open Ocean. The concentrations of $\mathrm{NO}_{\mathrm{x}}$ and the relationship with total peroxy radicals in Barbours Cut was similar to the Industrial Areas, although with lower $\mathrm{HO}_{2}+\Sigma \mathrm{RO}_{2}$ concentrations (Fig. 5). Average peroxy radicals mixing ratios in the Industrial Areas showed larger variability and were more influenced by outliers, probably because of individual emission plumes characterized by high levels of reactive VOC and $\mathrm{NO}_{\mathrm{x}}$ from nearby industrial complexes (the PERCA measurements frequency was $1 \mathrm{~min}$, sufficient to detect individual plumes). By contrast, peroxy radicals in Barbours Cut, which were farther from localized emissions and underwent more mixing and chemistry with the regional background air, were somewhat less variable.

\section{Photochemical formation of $\mathrm{O}_{3}$}

\subsection{Net photochemical ozone formation}

Total peroxy radical measurements have been used in several previous studies (e.g., Salisbury et al., 2002; Fleming et al., 2006; Parker et al., 2009) to calculate the net photochemical ozone formation rate $\left(\operatorname{Net}\left(\mathrm{O}_{3}\right)\right) \cdot \operatorname{Net}\left(\mathrm{O}_{3}\right)$ is defined as the difference between in-situ photochemical production and loss rates of ozone (Eq. 2). The production of ozone is 


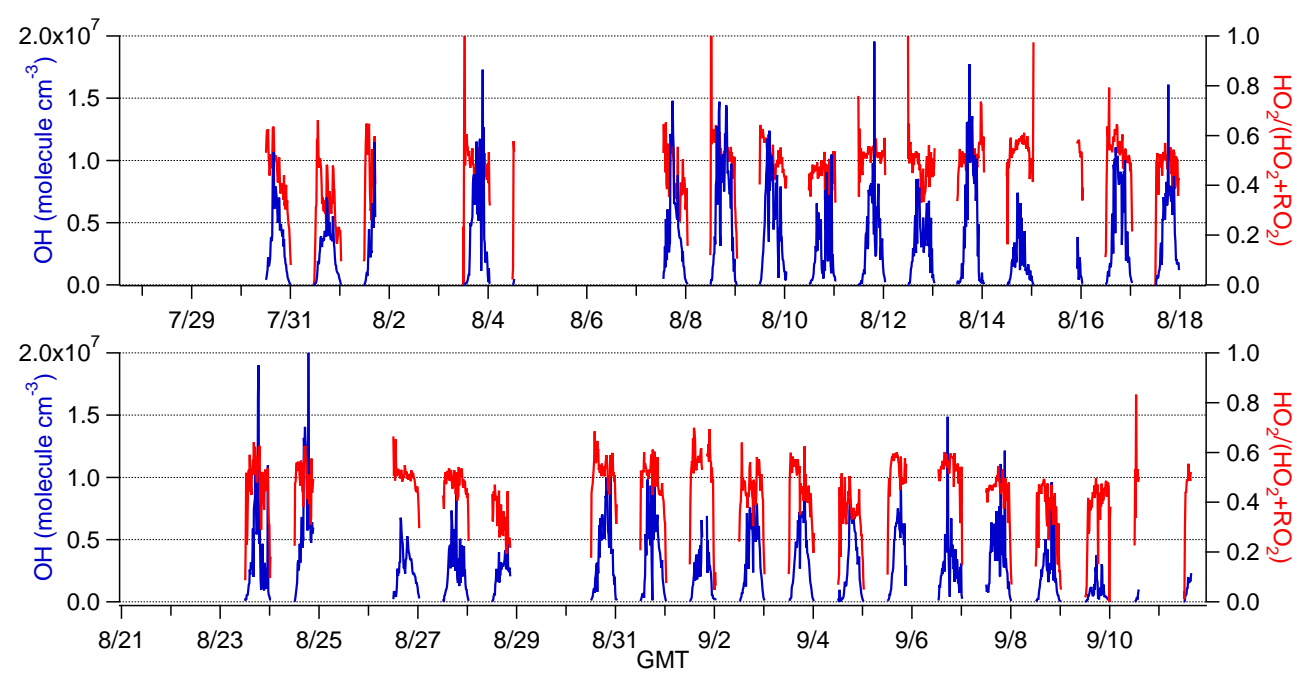

Fig. 7. $\mathrm{OH}$ and $\mathrm{HO}_{2} /\left(\mathrm{HO}_{2}+\Sigma \mathrm{RO}_{2}\right)$ calculated with the $\mathrm{MCM}$ box-model.

equivalent to the formation rate of $\mathrm{NO}_{2}$, whose photolysis is the only known mechanism for ozone formation in the troposphere (Reaction R2), via the reaction of $\mathrm{HO}_{2}$ and organic peroxy radicals with NO (Eq. 3). The loss of ozone is equal to its photolysis rate times the fraction ( $f$ in Eq. 5, where $k_{\mathrm{O}^{1} \mathrm{D}+\mathrm{M}}$ is the average of $k_{\mathrm{O}^{1} \mathrm{D}+\mathrm{N}_{2}}$ and $k_{\mathrm{O}^{1} \mathrm{D}+\mathrm{O}_{2}}$ weighted by the abundances of $\mathrm{N}_{2}$ and $\left.\mathrm{O}_{2}\right)$ of the $\mathrm{O}\left({ }^{1} \mathrm{D}\right)$ product that goes on to react with water vapor rather than quenching to produce ground-state atomic oxygen and, ultimately, reform ozone. Ozone is also lost via reactions with $\mathrm{OH}$ and $\mathrm{HO}_{2}$ (Eq. 4). The reaction of ozone with $\mathrm{NO}$ forms $\mathrm{NO}_{2}$ which reforms $\mathrm{O}_{3}$, so it is neutral in terms of the ozone budget and not included in Eq. (4). Loss of ozone, as calculated here, includes only the direct terms involving $\mathrm{O}_{3}$ itself and does not include such indirect losses of ozone as removal of $\mathrm{O}_{\mathrm{x}}$.

The rate coefficient used for $\mathrm{RO}_{2}+\mathrm{NO}$ was $2.54 \times 10^{-12} *$ $\exp (360 / T) \mathrm{cm}^{3}$ molecule ${ }^{-1} \mathrm{~s}^{-1}$, which is the generic value used in the Master Chemical Mechanism (MCM, http://mcm. leeds.ac.uk/) for all $\mathrm{RO}_{2}+\mathrm{NO}$ reactions for which no experimental values are available. The other rate coefficients were taken from the 2007 IUPAC evaluation (Atkinson et al., 2006).

$$
\begin{aligned}
& \operatorname{Net}\left(\mathrm{O}_{3}\right)=\operatorname{Prod}\left(\mathrm{O}_{3}\right)-\operatorname{Loss}\left(\mathrm{O}_{3}\right) \\
& \operatorname{Prod}\left(\mathrm{O}_{3}\right)=\left(k_{\mathrm{HO}_{2}+\mathrm{NO}} \cdot\left[\mathrm{HO}_{2}\right]+k_{\mathrm{RO}_{2}+\mathrm{NO}} \cdot\left[\mathrm{RO}_{2}\right]\right) \cdot[\mathrm{NO}] \\
& \operatorname{Loss}\left(\mathrm{O}_{3}\right)=\left(f * j\left(\mathrm{O}^{1} \mathrm{D}\right)+k_{\mathrm{OH}+\mathrm{O}_{3}} \cdot[\mathrm{OH}]+k_{\mathrm{HO}_{2}+\mathrm{O}_{3}} \cdot\left[\mathrm{HO}_{2}\right]\right) \cdot\left[\mathrm{O}_{3}\right] \\
& f=\frac{k_{\mathrm{O}^{1} \mathrm{D}+\mathrm{H}_{2} \mathrm{O}} \cdot\left[\mathrm{H}_{2} \mathrm{O}\right]}{k_{\mathrm{O}^{1} \mathrm{D}+\mathrm{H}_{2} \mathrm{O}} *\left[\mathrm{H}_{2} \mathrm{O}\right]+k_{\mathrm{O}^{1} \mathrm{D}+\mathrm{M}} \cdot[\mathrm{M}]}
\end{aligned}
$$

Measurements of NO, $\mathrm{O}_{3}, j\left(\mathrm{O}^{1} \mathrm{D}\right)$ and $\mathrm{H}_{2} \mathrm{O}$ were used in Eqs. (3), (4), (5). A box-model based upon the MCM and constrained to the chemical and physical parameters measured on board the R/V Brown during the cruise was used to calculate $\mathrm{OH}$ and the $\mathrm{HO}_{2} /\left(\mathrm{HO}_{2}+\Sigma \mathrm{RO}_{2}\right)$ ratio (Fig. 7). The box-model contained the oxidation scheme of 65 measured VOC, plus a complete inorganic mechanism taken from the IUPAC evaluation and was constrained to the chemical and physical parameters measured on board the R/V Brown during the cruise. The MCM box-model setup and assumptions have been described in detail in previous publications (Sommariva et al., 2006, 2009). The PERCA measurements and the modelled $\mathrm{HO}_{2} /\left(\mathrm{HO}_{2}+\Sigma \mathrm{RO}_{2}\right)$ ratio were used to calculate $\mathrm{HO}_{2}$ and $\mathrm{RO}_{2}$ in Eqs. (3), (4).

A local sensitivity analysis was performed on the calculated $\operatorname{Prod}\left(\mathrm{O}_{3}\right), \operatorname{Loss}\left(\mathrm{O}_{3}\right)$ and $\operatorname{Net}\left(\mathrm{O}_{3}\right)$ to assess the relative importance of each parameter and of the assumptions made. The local sensitivity analysis was made by varying the value of the input parameters in Eqs. (2), (3) and (4) (i.e., $\mathrm{NO}, \mathrm{O}_{3}, \mathrm{HO}_{2}+\Sigma \mathrm{RO}_{2}, k_{\mathrm{HO}_{2}+\mathrm{NO}}, k_{\mathrm{RO}_{2}+\mathrm{NO}}, k_{\mathrm{HO}_{2}+\mathrm{O}_{3}}$, $j\left(\mathrm{O}^{1} \mathrm{D}\right), \mathrm{HO}_{2} /\left(\mathrm{HO}_{2}+\Sigma \mathrm{RO}_{2}\right)$ and $\left.\mathrm{OH}\right)$ by $\pm 1 \%$. The percent variation in the calculated $\operatorname{Prod}\left(\mathrm{O}_{3}\right), \operatorname{Loss}\left(\mathrm{O}_{3}\right)$ and $\operatorname{Net}\left(\mathrm{O}_{3}\right)$ is indicated as $\Delta X^{ \pm 1 \%}$ and used to calculate the sensitivity index (SI, Eq. 6) for each of these parameters.

$S I=\frac{\% \Delta X^{+1 \%}-\% \Delta X^{-1 \%}}{100 \times 0.02}$

The results of the local sensitivity analysis are shown in Table 2 as campaign averages of the calculated SI. Photochemical production and loss rates of $\mathrm{O}_{3}$ were not very sensitive to the calculated concentration of $\mathrm{OH}$ or to the calculated $\mathrm{HO}_{2} /\left(\mathrm{HO}_{2}+\Sigma \mathrm{RO}_{2}\right)$ ratio, but they were sensitive to the concentrations of $\mathrm{NO}, \mathrm{O}_{3}$ and $\mathrm{HO}_{2}+\Sigma \mathrm{RO}_{2}$, which were measured in-situ. The net photochemical ozone formation rate was most sensitive to $\mathrm{NO}$ and $\mathrm{HO}_{2}+\Sigma \mathrm{RO}_{2}$, whose overall uncertainty was $3.8 \%$ (Sect. 2.2) and $40 \%$ (Sect. 2.1), respectively.

The net photochemical ozone formation rate was also very sensitive to $k_{\mathrm{RO}_{2}+\mathrm{NO}}$ (Table 2), a generic rate coefficient for 
Table 2. Campaign average of sensitivity indexes (Eq. 6) for $\operatorname{Prod}\left(\mathrm{O}_{3}\right), \operatorname{Loss}\left(\mathrm{O}_{3}\right)$ and $\operatorname{Net}\left(\mathrm{O}_{3}\right)$.

\begin{tabular}{lccc}
\hline Parameter & $\operatorname{Prod}\left(\mathrm{O}_{3}\right)$ & $\operatorname{Loss}\left(\mathrm{O}_{3}\right)$ & $\operatorname{Net}\left(\mathrm{O}_{3}\right)$ \\
\hline $\mathrm{NO}$ & 1 & - & 0.89 \\
$\mathrm{O}_{3}$ & - & 1 & 0.11 \\
$\mathrm{HO}_{2}+\Sigma \mathrm{RO}_{2}$ & 1 & 0.18 & 0.90 \\
$k_{\mathrm{HO}_{2}+\mathrm{NO}}$ & 0.36 & - & 0.32 \\
$k_{\mathrm{RO}_{2}+\mathrm{NO}}$ & 0.63 & - & 0.57 \\
$k_{\mathrm{HO}_{2}+\mathrm{O}_{3}}$ & - & 0.18 & 0.01 \\
$j\left(\mathrm{O}^{1} \mathrm{D}\right)$ & - & 0.75 & 0.09 \\
$\mathrm{HO}_{2} /\left(\mathrm{HO}_{2}+\Sigma \mathrm{RO}_{2}\right)$ & 0.02 & 0.18 & 0.03 \\
$\mathrm{OH}$ & - & 0.07 & 0.01 \\
\hline
\end{tabular}

the reaction of organic peroxy radicals with NO. The composition of the peroxy radical pool was unknown; therefore, all organic peroxy radicals had to be considered as a single species for the purpose of this calculation. In principle, the MCM box-model could yield this information; however experimental kinetic data are not available for every individual species in the MCM, so a generic rate coefficient would have to be used regardless. The error in this assumption is difficult to estimate, but, considering the typical uncertainty range of known reactions involving peroxy radicals $(15-60 \%)$, it is probably comparable to the uncertainty in the $\mathrm{HO}_{2}+\Sigma \mathrm{RO}_{2}$ measurements (Sect. 2.1).

To estimate the impact of the two most sensitive parameters, $\operatorname{Net}\left(\mathrm{O}_{3}\right)$ was recalculated changing $\mathrm{HO}_{2}+\Sigma \mathrm{RO}_{2}$ and $k_{\mathrm{RO}_{2}+\mathrm{NO}}$ by their uncertainties $( \pm 40 \%$ and $\pm 30 \%$, respectively). On average, $\operatorname{Net}\left(\mathrm{O}_{3}\right)$ changed by $\pm 40 \%$, when varying $\mathrm{HO}_{2}+\Sigma \mathrm{RO}_{2}$, and by $\pm 18 \%$, when varying $k_{\mathrm{RO}_{2}+\mathrm{NO}}$. The results indicate that measured $\mathrm{HO}_{2}+\Sigma \mathrm{RO}_{2}$ was the most critical parameter in determining $\operatorname{Net}\left(\mathrm{O}_{3}\right)$.

\subsection{Ozone formation during the $\mathrm{R} / \mathrm{V}$ Brown cruise}

The net photochemical formation rate, $\operatorname{Net}\left(\mathrm{O}_{3}\right)$, calculated with Eq. (2) during daylight hours was divided on the basis of the location of the R/V Brown, in the same way as the $\mathrm{HO}_{2}+\Sigma \mathrm{RO}_{2}$ data (Sect. 3). The median profiles of $\operatorname{Prod}\left(\mathrm{O}_{3}\right)$ and $\operatorname{Loss}\left(\mathrm{O}_{3}\right)$ in each location are shown in Fig. 8. Photochemical production (Eq. 3) was 1-2 orders of magnitude higher than photochemical loss (Eq. 4) in all areas, except in the Open Ocean, where the two components of Eq. (2) had similar magnitude, resulting sometimes in net photochemical ozone destruction (negative $\left.\operatorname{Net}\left(\mathrm{O}_{3}\right)\right)$. $\operatorname{Loss}\left(\mathrm{O}_{3}\right)$ was similar in all locations $(0.5-1 \mathrm{ppb} / \mathrm{h})$, because the main component in Eq. (4) was the photolysis of ozone, which accounted typically for $70-95 \%$ of $\operatorname{Loss}\left(\mathrm{O}_{3}\right)$. This also explains the characteristic diurnal variation of photochemical ozone loss in Fig. 8.

The lowest median values of $\operatorname{Prod}\left(\mathrm{O}_{3}\right)$ were observed in the Open Ocean and along the Gulf Coast $(0.6-12 \mathrm{ppb} / \mathrm{h})$, while the highest median values of $\operatorname{Prod}\left(\mathrm{O}_{3}\right)$ were observed
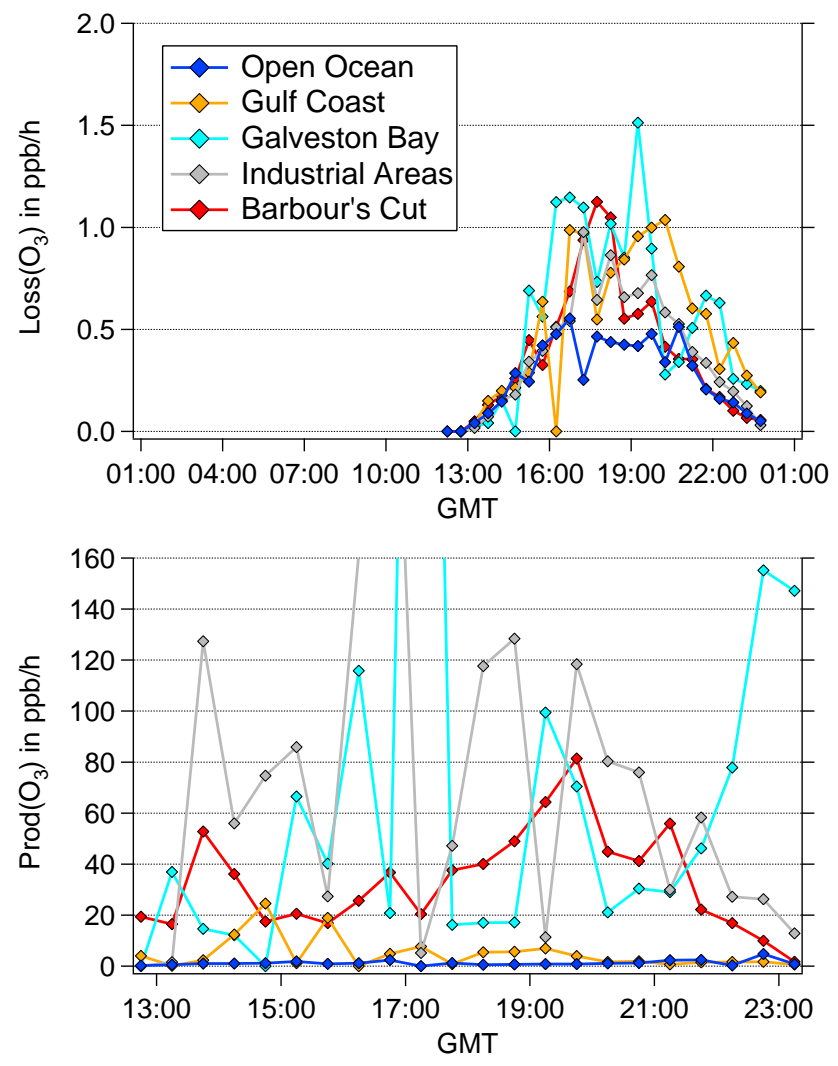

Fig. 8. Median profiles of $\operatorname{Loss}\left(\mathrm{O}_{3}\right)$ and $\operatorname{Prod}\left(\mathrm{O}_{3}\right)$ at different locations during the R/V Brown cruise.

in Galveston Bay and Industrial Areas (up to $100 \mathrm{ppb} / \mathrm{h}$ ). $\operatorname{Prod}\left(\mathrm{O}_{3}\right)$ decreased in the afternoon in the Gulf Coast, Barbours Cut and in the Industrial Areas (Fig. 8), largely because of the decrease in the $\mathrm{HO}_{2}+\Sigma \mathrm{RO}_{2}$ concentrations. In the Open Ocean and Galveston Bay, photochemical formation of ozone was sustained in the late afternoon by increasing levels of $\mathrm{HO}_{2}+\Sigma \mathrm{RO}_{2}$ (Figs. 5, 6), probably related to oxygenated VOC, which photolyze at longer wavelengths and act as radical precursors in these areas (Sect. 3).

The high values of $\operatorname{Prod}\left(\mathrm{O}_{3}\right)$ shown in Fig. 8 resulted in high values of net photochemical ozone production, particularly in Barbours Cut, Galveston Bay and in the Industrial Areas. The high production rates were comparable to those observed and calculated at the LaPorte site during the previous TexAQS 2000 campaign (see Sect. 4.3) and were mostly driven by high concentrations of NO (Eq. 3). In Barbours Cut and in the Industrial Areas, the median mixing ratios of NO were $7.4 \mathrm{ppb}$ and $13 \mathrm{ppb}$, respectively, which led to production rates on the order of tens to hundreds of $\mathrm{ppb} / \mathrm{h}$. While high, these values are not uncommon. Kleinman et al. (2005) reported ozone production rates on the order of tens of $\mathrm{ppb} / \mathrm{h}$ in several US urban areas and, in particular, in Houston, Texas, where production rates were up to $155 \mathrm{ppb} / \mathrm{h}$. The higher ozone production rates in Houston compared to other 

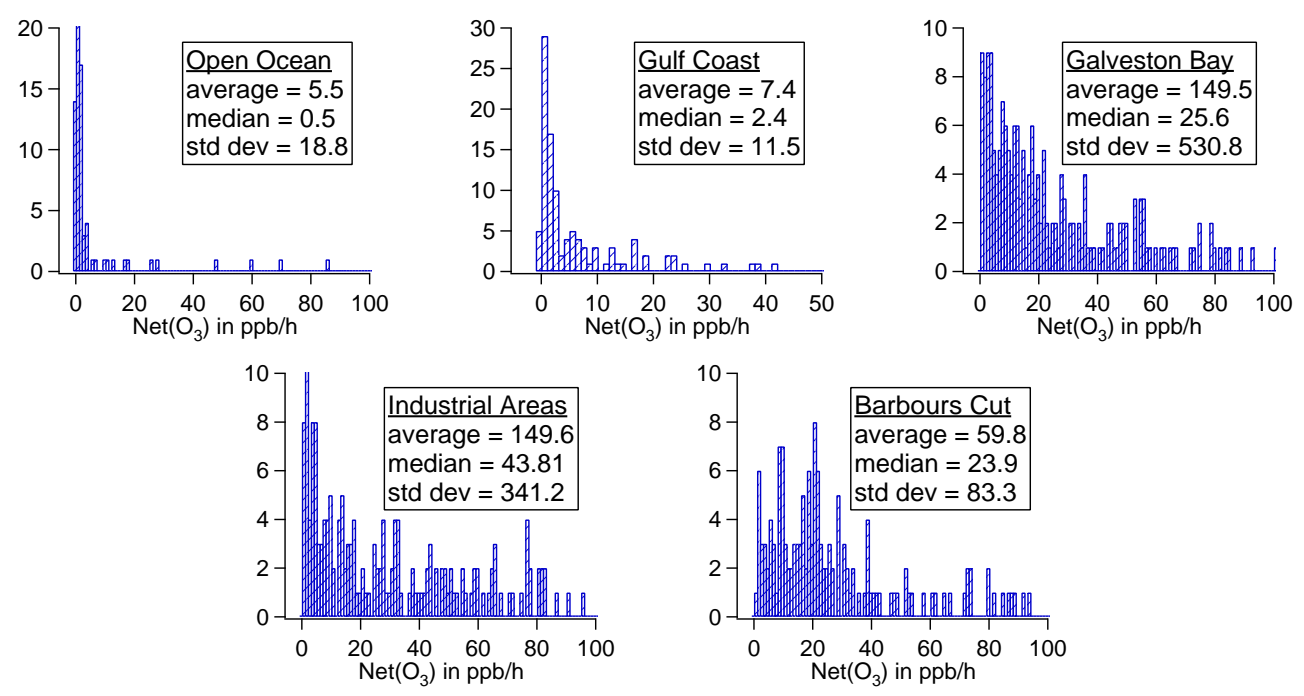

Fig. 9. Frequency distributions of $\operatorname{Net}\left(\mathrm{O}_{3}\right)$ at different locations during the $\mathrm{R} / \mathrm{V}$ Brown cruise. The bin size is $0.1 \mathrm{ppb} / \mathrm{h}$ for Open Ocean and $1 \mathrm{ppb} / \mathrm{h}$ for all the other locations. The values on the $y$-axis are the number of data points in each bin.

urban areas were attributed to the co-location of $\mathrm{NO}_{\mathrm{x}}$ and highly reactive olefins emissions from the petrochemical plants in the Houston/Galveston area. Kleinman et al. (2005) also noted, by looking at data from Philadelphia, Pennsylvania, and Phoenix, Arizona, that morning and afternoon ozone production rates were generally comparable. Although a straightforward comparison is not possible, this is consistent with the data presented in this work (Fig. 8).

The occurrence of a large number of high $\operatorname{Prod}\left(\mathrm{O}_{3}\right)$ episodes was likely related to sampling of individual plumes characterized by high concentrations of $\mathrm{NO}_{\mathrm{x}}$ and reactive VOC, especially in the Industrial Areas. This tends to bias the analysis of the measurements towards higher values. To better understand the probability of such events, the net photochemical ozone formation rate $\left(\operatorname{Net}\left(\mathrm{O}_{3}\right)\right.$, Eq. 2) at different locations of the R/V Brown cruise is shown in Fig. 9 as frequency distributions. Except in the Open Ocean, $\operatorname{Net}\left(\mathrm{O}_{3}\right)$ was positive, indicating that these were all ozone producing areas. In the Open Ocean, ozone destroying conditions were often encountered, when very clean air masses from the central Gulf of Mexico or from the Atlantic Ocean were sampled (Fig. 9). The median $\operatorname{Net}\left(\mathrm{O}_{3}\right)$ was $0.5 \mathrm{ppb} / \mathrm{h}$ in Open Ocean, although the average value was higher $(5.5 \mathrm{ppb} / \mathrm{h})$. In the Gulf Coast, the median $\operatorname{Net}\left(\mathrm{O}_{3}\right)$ was $2.4 \mathrm{ppb} / \mathrm{h}$ (and the average $7.4 \mathrm{ppb} / \mathrm{h}$ ). These values are comparable to the net ozone formation rates reported by previous studies in the semi-polluted and clean marine boundary layer (e.g., Salisbury et al., 2002; Fleming et al., 2006).

In all locations, the median $\operatorname{Net}\left(\mathrm{O}_{3}\right)$ was much lower than the average $\operatorname{Net}\left(\mathrm{O}_{3}\right)$ because of the presence of a large number of outliers (Fig. 9). This was related to the high variability in the local emissions, particularly in the Industrial Areas, where a clear distribution of the $\operatorname{Net}\left(\mathrm{O}_{3}\right)$ values was not evi- dent. It implies that the measurements taken in the Industrial Areas were a collection of individual plumes from different industrial sources rather than representative of the area as a whole. This is also true for Galveston Bay data, which were likely influenced by emissions from passing ships, tugboats and barges. $\operatorname{Net}\left(\mathrm{O}_{3}\right)$ was very high in the Industrial Areas, Barbours Cut and Galveston Bay with values in the range of tens up to hundreds of $\mathrm{ppb} / \mathrm{h}$. The median $\operatorname{Net}\left(\mathrm{O}_{3}\right)$ in the Industrial Areas was $43.8 \mathrm{ppb} / \mathrm{h}$, although values as high as several hundreds of $\mathrm{ppb} / \mathrm{h}$ were as frequent as lower values (Fig. 9). In Barbours Cut and Galveston Bay the median $\operatorname{Net}\left(\mathrm{O}_{3}\right)$ was similar, between 23 and $26 \mathrm{ppb} / \mathrm{h}$, but the average was lower in Barbours Cut ( 60 vs. $150 \mathrm{ppb} / \mathrm{h}$ ), because of the lower $\mathrm{HO}_{2}+\Sigma \mathrm{RO}_{2}$ concentrations measured in this location (Sect. 3). Ozone formation in Barbours Cut is discussed in more detail in Sect. 4.3 in relation to VOC reactivity and the geographical distribution of the emission sources around the commercial shipping dock (Fig. 3b).

Sustained photochemical ozone formation rates on the order of tens or even hundreds of $\mathrm{ppb} / \mathrm{h}$ would rapidly generate extremely high concentrations of ozone, much larger than observed by, for example, the ozone monitoring network around the Houston area. Kleinman et al. (2005) noted that while high ozone events were preceded by periods of high $\operatorname{Prod}\left(\mathrm{O}_{3}\right)$, not all periods of high $\operatorname{Prod}\left(\mathrm{O}_{3}\right)$ necessarily led to high ozone events. This is because dilution also plays an important role in determining the downwind concentration of ozone and can be more important than the photochemical processes (Banta et al., 2005; Tucker et al., 2010). For example, during TexAQS 2006, Langford et al. (2009) found that high photochemical activity on 4 August resulted in comparatively low ozone concentrations because of the strong winds that lowered the regional ozone background. 


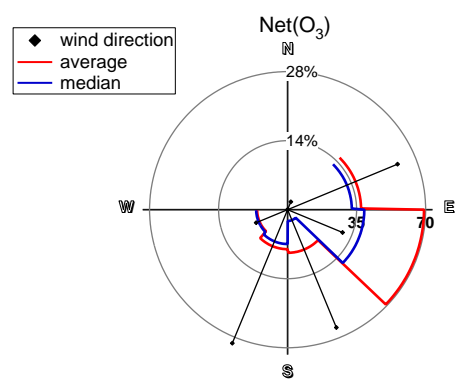

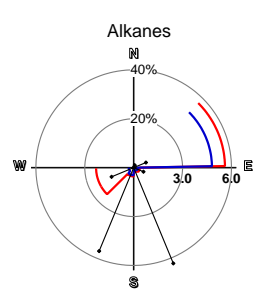
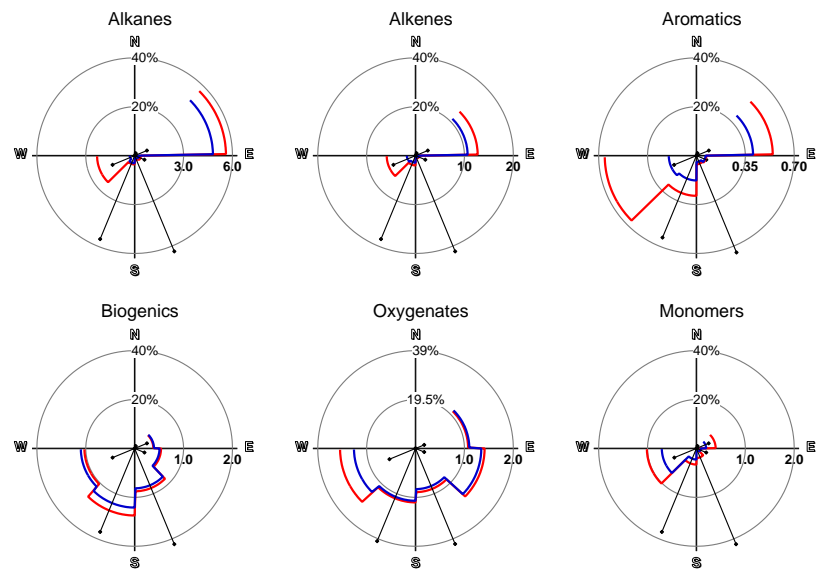

Fig. 10. $\operatorname{Net}\left(\mathrm{O}_{3}\right)$ (in $\mathrm{ppb} / \mathrm{h}$ ) and $\mathrm{OH}$ reactivity of VOC classes (in $\mathrm{s}^{-1}$ ) as function of local wind direction in Barbours Cut during TexAQS 2006. The values on the $x$-axis are the medians (blue) and the averages (red); the values on the $y$-axis indicate the frequency of the wind direction.

\subsection{Ozone formation in Barbours Cut}

In Barbours Cut (Fig. 3), the R/V Brown was either docked or stationary and therefore it is possible to analyze the net photochemical $\mathrm{O}_{3}$ formation on the basis of the local wind direction and relate $\operatorname{Net}\left(\mathrm{O}_{3}\right)$ to the sources around the shipping dock. Figure 10 shows $\operatorname{Net}\left(\mathrm{O}_{3}\right)$ and local wind direction polar distributions for Barbours Cut together with the $\mathrm{OH}$ reactivity of different classes of VOC (measured in $\mathrm{s}^{-1}$ as $1 / \tau_{\mathrm{OH}}$, where $\tau_{\mathrm{OH}}$ is the lifetime of a VOC with respect to reaction with $\mathrm{OH}$ ). The S-SW and S-E sectors were the most frequently sampled during the period when the R/V Brown was in Barbours Cut, while only occasionally air masses coming from $\mathrm{N}$ and $\mathrm{NW}$ sectors were sampled.

The highest values of $\operatorname{Net}\left(\mathrm{O}_{3}\right)$ were measured when the wind was from the E-SE and E-NE sector (Fig. 10). Given the location of Barbours Cut (Fig. 3b), these correspond to air masses that had spent some time over Galveston Bay. As explained earlier (Sect. 2.3) and discussed in previous work (Banta et al., 1998, 2005), the particular meteorology of the area can lead to stagnant conditions around the northern shore of Galveston Bay, leading to a buildup of ozone concentrations that are then transported back over Houston by the onshore sea breeze.
The $\mathrm{OH}$ reactivities of different VOC classes can be used to investigate which species most influenced $\mathrm{O}_{3}$ formation in different sectors. Alkenes clearly were the dominant class of reacting VOC, with values of $1 / \tau_{\mathrm{OH}}$ on the order of tens of $\mathrm{s}^{-1}$ (Fig. 10), followed by alkanes, biogenics, oxygenates and monomers (e.g., 1,3-butadiene and vinyl acetate), with values of $1 / \tau_{\mathrm{OH}}$ on the order of a few $\mathrm{s}^{-1}$. Aromatics, halogenated VOC and nitrogen or sulphur containing VOC (such as DMS) showed the lowest reactivity to OH (Fig. 10). This is consistent with the analysis of Gilman et al. (2009), who showed that the concentration of $\mathrm{OH}$ was controlled by alkenes, $\mathrm{C} 2-\mathrm{C} 4$ alkanes and highly reactive species, such as isoprene, oxygenates, 1,3-butadiene and vinyl acetate. Although there are industrial sources of isoprene, Gilman et al. (2009) concluded that isoprene in the Houston area is mostly biogenic in origin.

The importance of the different classes in each sector was varied and was dependent on the emission sources surrounding Barbours Cut. Alkanes, alkenes and monomers showed a similar pattern, which can be traced to common emissions of industrial origin. These species were most important in air masses from the E-NE and W-SW sectors (Fig. 10), corresponding to industries on either side of the Houston Ship Channel (Fig. 3b). Aromatics, although much less reactive, contributed to the $\mathrm{OH}$ reactivity in these air masses and also in air masses from the S-SW sector (Fig. 10). The different pattern of aromatics is related to the fact that these species are of urban (i.e., traffic) as well as industrial origin and therefore impacted a broader range of air masses. In the SW, $\mathrm{S}$ and SE sectors, $\mathrm{OH}$ reactivity was largely controlled by biogenic and oxygenated VOC. The S-SW sector, in particular, was dominated by biogenics (mostly isoprene) and their oxygenated products, such as methyl vinyl ketone and methacrolein (Gilman et al., 2009). The E-SE sector was almost completely dominated by oxygenated VOC (Fig. 10), the most important of which was formaldehyde. The main source of $\mathrm{HCHO}$ was determined to be secondary formation from the oxidation of hydrocarbons rather than primary emission (Gilman et al., 2009). As explained earlier, these air masses were recirculated from Galveston Bay and contained more processed air.

To summarize, the highest net ozone formation rates were measured in the E-SE sector and the most important precursors were oxygenated VOC and, to a lesser extent, biogenic VOC (Fig. 10). In the E-NE and in the W-SW sectors, on the other hand, the most important ozone precursors were alkenes, followed by alkanes and monomers (Fig. 10). Biogenics, followed by oxygenates, were the most important precursors in the S-SW sector (Fig. 10). Other species, such as aromatics and halogenated VOC, contributed very little to reactivity of $\mathrm{OH}$ and hence to the formation of ozone, either because of lower emissions or because of slower oxidation rates.

The measurements taken in Barbours Cut can be compared with those taken at LaPorte airport during the previous 

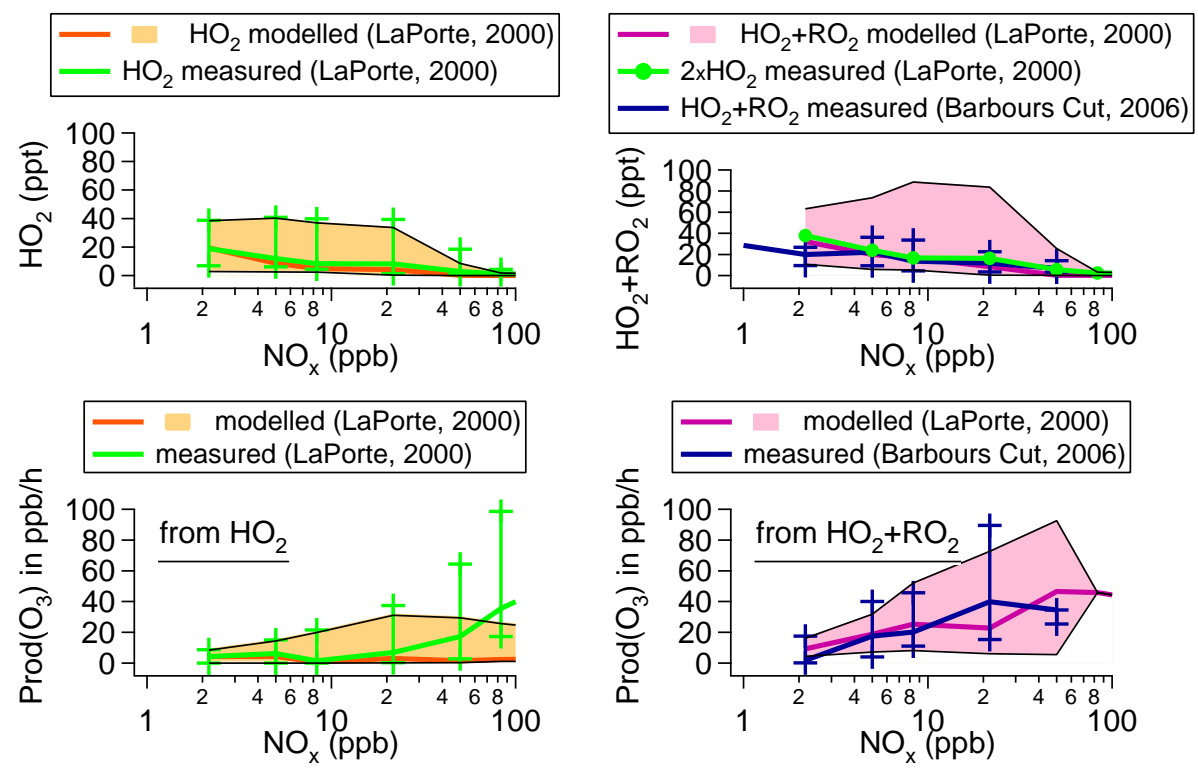

Fig. 11. Comparison of modelled (with the TexAQS 2000 model) and measured $\mathrm{HO}_{2}, \mathrm{HO}_{2}+\Sigma \mathrm{RO}_{2}$ and $\operatorname{Prod}\left(\mathrm{O}_{3}\right)$ in $\mathrm{LaPorte}(2000)$ and Barbours Cut (2006). The shaded areas and the bars indicate the 10-th and 90-th percentiles.

TexAQS 2000 campaign. LaPorte is only $6 \mathrm{~km}$ west of Barbours Cut (Fig. 3b). In 2000, $\mathrm{HO}_{2}$ was measured by laserinduced fluorescence (Mao et al., 2010), but there were no measurements of organic peroxy radicals. Therefore, a direct comparison between the measurements in 2000 and in 2006 is not possible. However, a model can be used as a proxy to compare the 2000 and 2006 observations. The model, described in detail in Frost et al. (1999), was tailored for the 2000 campaign and constrained to the measurements taken at LaPorte, Texas.

In Fig. 11, modelled $\mathrm{HO}_{2}$ and $\mathrm{HO}_{2}+\Sigma \mathrm{RO}_{2}$ were compared to measured $\mathrm{HO}_{2}$ and $2 \times \mathrm{HO}_{2}$, respectively, for the 2000 campaign at LaPorte; $2 \times \mathrm{HO}_{2}$ was used as an estimate of total peroxy radicals, a reasonable assumption in urban influenced outflow (Wood et al., 2009). The model results, which agree with the results of the MCM box-model used in $\mathrm{Sec} 4.1$, support the hypothesis that $\mathrm{HO}_{2}$ was approximately half of the total peroxy radicals pool (Fig. 7).

The model generally underestimated the measurements, although the range of the model results was within the variability of the measurements (Fig. 11). The modelled and measured medians $\mathrm{HO}_{2}$ agreed to within $27-48 \%$, while the the modelled $\mathrm{HO}_{2}+\Sigma \mathrm{RO}_{2}$ and measured $2 \times \mathrm{HO}_{2}$ medians agreed to within $15-47 \%$. Given an instrumental uncertainty of $\sim 40 \%$ (Mao et al., 2010) the agreement can be considered satisfactory. The estimated median concentration of $\mathrm{HO}_{2}+\Sigma \mathrm{RO}_{2}$ in 2000 (i.e., $2 \times$ measured $\mathrm{HO}_{2}$ ), was comparable, within $30 \%$, to the median concentration of $\mathrm{HO}_{2}+\Sigma \mathrm{RO}_{2}$ measured at Barbours Cut in 2006, and showed a similar dependence on $\left[\mathrm{NO}_{\mathrm{x}}\right]$ (Fig. 11).
In-situ $\mathrm{O}_{3}$ photochemical production $\left(\operatorname{Prod}\left(\mathrm{O}_{3}\right)\right.$, Eq. 3$)$ was calculated using only $\mathrm{HO}_{2}$ for the 2000 campaign: the agreement between the modelled and measured $\operatorname{Prod}\left(\mathrm{O}_{3}\right)$ medians was within $30 \%$ for $\left[\mathrm{NO}_{\mathrm{x}}\right]<20-30 \mathrm{ppb}$. At higher $\left[\mathrm{NO}_{\mathrm{x}}\right]$, measured $\operatorname{Prod}\left(\mathrm{O}_{3}\right)$ showed a steep increase, while modelled $\operatorname{Prod}\left(\mathrm{O}_{3}\right)$ decreased (Fig. 11). It must be noted, however, that the $\mathrm{HO}_{2}$ data points observed at $\left[\mathrm{NO}_{\mathrm{x}}\right]$ $<50 \mathrm{ppb}$ were few and scattered, which might bias the calculation. $\operatorname{Prod}\left(\mathrm{O}_{3}\right)$ calculated using $\mathrm{HO}_{2}+\Sigma \mathrm{RO}_{2}$ from the TexAQS 2000 model was then compared with the one calculated from the $\mathrm{HO}_{2}+\Sigma \mathrm{RO}_{2}$ measurements in TexAQS 2006 in Fig. 11. Despite the difference in space and time between the two datasets, there was reasonable agreement (median values within 20-40\%). $\operatorname{Prod}\left(\mathrm{O}_{3}\right)$ from the 2006 PERCA measurements showed similar $\mathrm{NO}_{\mathrm{x}}$ dependence as $\operatorname{Prod}\left(\mathrm{O}_{3}\right)$ calculated with the 2000 model with a maximum centered around 30-40 ppb (Fig. 11).

The comparisons illustrated in Fig. 11 suggests that conditions in LaPorte in 2000 and in Barbours Cut in 2006 were very similar. The level of $\left[\mathrm{NO}_{\mathrm{x}}\right]$ was somewhat lower in 2006, consistent with other observations (Parrish et al., 2009) and ozone production remained $\mathrm{NO}_{\mathrm{x}}$-limited in this area, likely because of the abundance of VOC emitted from the surrounding industries.

\section{Summary and conclusions}

Measurements of total peroxy radicals $\left(\mathrm{HO}_{2}+\Sigma \mathrm{RO}_{2}\right)$ were made during the TexAQS 2006 cruise of the R/V Brown with a dual-channel PEroxy Radical Chemical Amplifier (PERCA). The ship sailed across the Gulf of Mexico and 
along the Gulf coast of Texas, spending most of the time in the highly industrialized Houston/Galveston region.

Mixing Ratios of $\mathrm{HO}_{2}+\Sigma \mathrm{RO}_{2}$ ranged from 25 to $110 \mathrm{ppt}$ during the day and from 5 to $25 \mathrm{ppt}$ (with a campaign maximum of $134 \mathrm{ppt}$ ) during the night. The data were divided according to the location of the R/V Brown into five areas - Open Ocean, Gulf Coast, Galveston Bay, Industrial Areas and Barbours Cut (Fig. 3) - and analyzed in conjunction with measurements of nitrogen oxides, VOC, photolysis rates and ${ }^{222}$ Radon, in order to assess the differences between the 5 regions in terms of radical sources and sinks. The lowest $\mathrm{HO}_{2}+\Sigma \mathrm{RO}_{2}$ mixing ratios (30-35 ppt) were observed in the Open Ocean and were mostly related to the reactivity of $\mathrm{CO}$, $\mathrm{CH}_{4}$ and oxygenated VOC. The highest $\mathrm{HO}_{2}+\Sigma \mathrm{RO}_{2}$ mixing ratios $(45-50 \mathrm{ppt})$ were observed in the Industrial Areas and were related to highly reactive VOC (e.g., alkenes, isoprene, butadiene).

The measurements of total peroxy radicals were used to calculate instantaneous in-situ photochemical production $\left(\operatorname{Prod}\left(\mathrm{O}_{3}\right)\right)$ and $\operatorname{loss}\left(\operatorname{Loss}\left(\mathrm{O}_{3}\right)\right)$ rates of ozone and the net photochemical ozone formation rate $\left(\operatorname{Net}\left(\mathrm{O}_{3}\right)=\operatorname{Prod}\left(\mathrm{O}_{3}\right)\right.$ $\left.\operatorname{Loss}\left(\mathrm{O}_{3}\right)\right)$. The median net photochemical ozone formation rates ranged from $0.5 \mathrm{ppb} / \mathrm{h}$ in the Open Ocean to $44 \mathrm{ppb} / \mathrm{h}$ in the Industrial Areas, which is consistent with previous studies. Ozone destroying conditions $\left(\operatorname{Net}\left(\mathrm{O}_{3}\right)<0 \mathrm{ppb} / \mathrm{h}\right)$ were also found in very clean air masses from the open Atlantic Ocean or Gulf of Mexico. Net photochemical ozone formation rates in the Industrial Areas were heavily affected by individual plumes, rich in highly reactive VOC from petrochemical industries, leading to $\operatorname{Net}\left(\mathrm{O}_{3}\right)$ values of several tens of $\mathrm{ppb} / \mathrm{h}$. Such high ozone formation rates are characteristic of near-source regions and are limited in both time and space (e.g., related to single intermittent plumes).

The net photochemical ozone formation rates determined in Barbours Cut, south of the Houston Ship Channel, were analyzed in relation to local wind direction and VOC reactivity. The highest $\operatorname{Net}\left(\mathrm{O}_{3}\right)$ were measured in air masses from the E-SE sector (i.e., from the Bay of Galveston) and were related mostly to oxygenated and biogenic VOC. Air masses from the E-NE and the W-SW sectors (i.e., from the Industrial Areas) were mostly related to alkenes, alkanes and monomers (e.g., 1,3-butadiene and vinyl acetate).

Finally, the results obtained during TexAQS 2006 were compared to the results obtained during the previous TexAQS 2000 campaign, when $\mathrm{HO}_{2}$ measurements were made at a nearby location (LaPorte airport, south of Houston and $6 \mathrm{~km}$ from Barbours Cut). A model tailored for the 2000 campaign was used as a proxy to compare the two datasets. The two datasets showed similar range of values and dependence on nitrogen oxides concentrations, indicating that ozone formation in the Houston area were $\mathrm{NO}_{\mathrm{x}}$-limited due to strong emissions of reactive VOC.
Acknowledgements. We would like to thank the crew of the NOAA R/V Brown for their help and assistance during the field campaign; S. Ciciora, W. P. Dubé, G. Hübler, T. Thompson for help with shipping and setting up the PERCA instrument; J. B. Burkholder for help in the determination of methyl iodide photolysis rate; T. Thornberry for software used in the data analysis. W. H. Brune, M. Martinez, H. Harder and P. Di Carlo for the TexAQS 2000 data. This work was supported by a grant from the Texas Commission on Environmental Quality.

Edited by: F. Keutsch

\section{References}

Andrés-Hernández, M. D., Stone, D., Brookes, D. M., Commane, R., Reeves, C. E., Huntrieser, H., Heard, D. E., Monks, P. S., Burrows, J. P., Schlager, H., Kartal, D., Evans, M. J., Floquet, C. F. A., Ingham, T., Methven, J., and Parker, A. E.: Peroxy radical partitioning during the AMMA radical intercomparison exercise, Atmos. Chem. Phys., 10, 10621-10638, doi:10.5194/acp10-10621-2010, 2010.

Atkinson, R., Cox, R. A., Crowley, J. N., Hampson, R. F., Hynes, R. G., Jenkin, M. E., Kerr, J. A., Rossi, M. J., and Troe, J.: Summary of evaluated kinetic and photochemical data for atmospheric chemistry, Tech. rep., IUPAC Subcommittee on Gas Kinetic Data Evaluation for Atmospheric Chemistry, http://www. iupac-kinetic.ch.cam.ac.uk/, 2006.

Banta, R. M., Senff, C. J., White, A. B., Trainer, M., McNider, R. T., Valente, R. J., Mayor, S. D., Alvarez, R. J., Hardesty, R. M., Parrish, D., and Fehsenfeld, F. C.: Daytime buildup and nighttime transport of urban ozone in the boundary layer during a stagnation episode, J. Geophys. Res., 103, 22519-22544, 1998.

Banta, R. M., Senff, C. J., Nielsen-Gammon, J., Darby, L. S., Ryerson, T. B., Alvarez, R. J., Sandberg, S. P., Williams, E. J., and Trainer, M.: A bad air day in Houston, B. Am. Meteorol. Soc., 86, 657-669, 2005.

Bates, T. S., Quinn, P. K., Coffman, D., Schulz, K., Covert, D. S., Johnson, J. E., Williams, E. J., Lerner, B. M., Angevine, W. M., Tucker, S. C., Brewer, W. A., and Stohl, A.: Boundary layer aerosol chemistry during TexAQS/GoMACCS 2006; insights into aerosol sources and transformation processes, J. Geophys. Res., 113, D00F01, doi:10.1029/2008JD010023, 2008.

Cantrell, C. A., Stedman, D. H., and Wendel, G. J.: Measurement of atmospheric peroxy radicals by chemical amplification, Anal Chem., 56, 1496-1502, 1984.

Cantrell, C. A., Shetter, R. E., and Calvert, J. G.: Dual-inlet chemical amplifier for atmospheric peroxy radical measurements, Anal. Chem., 68, 23, 4194-4199, 1996a.

Cantrell, C. A., Shetter, R. E., Gilpin, T. M., and Calvert, J. G.: Peroxy radicals measured during Mauna Loa Observatory Photochemistry Experiment 2: the data and first analysis, J. Geophys. Res., 101, 14643-14652, 1996 b.

Fleming, Z. L.: The measurement of peroxy radicals in the marine boundary layer using the PERCA technique, Ph.D thesis, University of Leicester, UK, 2005.

Fleming, Z. L., Monks, P. S., Rickard, A. R., Heard, D. E., Bloss, W. J., Seakins, P. W., Still, T. J., Sommariva, R., Pilling, M. J., Morgan, R., Green, T. J., Brough, N., Mills, G. P., Penkett, S. A., Lewis, A. C., Lee, J. D., Saiz-Lopez, A., and Plane, J. M. C.: Per- 
oxy radical chemistry and the control of ozone photochemistry at Mace Head, Ireland during the summer of 2002, Atmos. Chem. Phys., 6, 2193-2214, doi:10.5194/acp-6-2193-2006, 2006.

Frost, G. J., Trainer, M., Mauldin, R. L., Eisele, F. L., Prevot, A. S. H., Flocke, S. J., Madronich, S., Kok, G., Schillawski, R. D., Baumgarden, D., and Bradshaw, J.: Photochemical modeling of $\mathrm{OH}$ level during the First Areosol Characterization Experiment (ACE1), J. Geophys. Res., 104, 16041-16052, 1999.

Gilman, J. B., Kuster, W. C., Goldan, P. D., Herndon, S. C., Zahniser, M. S., Tucker, S. C., Brewer, W. A., Lerner, B. M., Williams, E. J., Harley, R. A., Fehsenfeld, F. C., Warneke, C., and de Gouw, J. A.: Measurements of volatile organic compounds during the 2006 TexAQS/GoMACCS campaign: industrial influences, regional characteristics, and diurnal dependencies of the OH reactivity, J. Geophys. Res., 114, D00F06, doi:10.1029/2008JD011525, 2009.

Green, T. J., Reeves, C. E., Fleming, Z. L., Brough, N., Rickard, A. R., Bandy, B. J., Monks, P. S., and Penkett, S. A.: An improved dual channel PERCA instrument for atmospheric measurements of peroxy radicals, J. Environ. Monitor., 8, 530-536, 2006.

Herndon, S. C., Zahniser, M. S., Nelson, D. D., Shorter, J., McManus, J. B., Jiménez, R., Warneke, C., and de Gouw, J. A.: Airborne measurements of $\mathrm{HCHO}$ and $\mathrm{HCOOH}$ during the New England Air Quality Study 2004 using a pulsed quantum cascade laser spectrometer, J. Geophys. Res., 112, D10S03, doi:10.1029/2006JD007600, 2007.

Jobson, B. T., Berkowitz, C. M., Kuster, W. C., Goldan, P. D., Williams, E. J., Fehsenfeld, F. C., Apel, E. C., Karl, T., Lonneman, W. A., and Riemer, D.: Hydrocarbon source signatures in Houston, Texas: influence of the petrochemical industry, J. Geophys. Res., 109, D24305, doi:10.1029/2004JD004887, 2004.

Kartal, D., Andrés-Hernández, M. D., Reichert, L., Schlager, H., and Burrows, J. P: Technical Note: Characterisation of a DUALER instrument for the airborne measurement of peroxy radicals during AMMA 2006, Atmos. Chem. Phys., 10, 30473062, doi:10.5194/acp-10-3047-2010, 2010.

Kleinman, L. I., Daum, P. H., Lee, Y., Nunnermacker, L. J., Springston, S. R., Weinstein-Lloyd, J., and Rudolph, J.: A comparative study of ozone production in five US metropolitan areas, J. Geophys. Res., 110, D02301, doi:10.1029/2004JD005096, 2005.

Langford, A. O., Senff, C. J., Banta, R. M., Hardesty, R. M., Alvarez, R. J., Sandberg, S. P., and Darby, L. S.: Regional and local background ozone in Houston during the Texas Air Quality Study 2006, J. Geophys. Res., 114, D00F12, doi:10.1029/2008JD011687, 2009.

Mao, J., Ren, X., Chen, S., Brune, W. H., Chen, Z., Martinez, M., Harder, H., Lefer, B., Rappenglück, B., Flynn, J., Leuchner, M.: Atmospheric oxidation capacity in the summer of Houston 2006: comparison with summer measurements in other metropolitan studies, Atmos. Environ., 44, 4107-4115, 2010.

Monks, P. S.: Gas-phase radical chemistry in the troposphere, Chem. Soc. Rev., 34, 376-395, 2005.

Monks, P. S., Carpenter, L. J., Penkett, S. A., Ayers, G. P., Gillett, R. W., Galbally, I. E., and Meyer, C. P.: Fundamental ozone photochemistry in the remote marine boundary layer: the SOAPEX experiment, measurement and theory, Atmos. Environ., 32, 3647-3664, 1998.
Olaguer, E. P., Rappenglück, B., Lefer, B., Stutz, J., Dibb, J., Griffin, R., Brune, W. H., Shauck, M., Buhr, M., Jeffries, H., Vizuete, W., and Pinto, J. P.: Deciphering the role of radical precursors during the Second Texas Air Quality Study, J. Air Waste Manage. Assoc., 59, 1258-1277, 2009.

Osthoff, H. D., Sommariva, R., Baynard, T., Pettersson, A., Williams, E. J., Lerner, B. M., Roberts, J. M., Stark, H., Goldan, P. D., Kuster, W. C., Bates, T. S., Coffman, D., Ravishankara, A. R., and Brown, S. S.: Observation of daytime $\mathrm{N}_{2} \mathrm{O}_{5}$ in the marine boundary layer during New England Air Quality StudyIntercontinental Transport and Chemical Transformation 2004, J. Geophys. Res., 111, D23S14, doi:10.1029/2006JD007593, 2006.

Parker, A. E., Monks, P. S., Wyche, K. P., Balzani-Lv, J. M., Staehelin, J., Reimann, S., Legreid, G., Vollmer, M. K., and Steinbacher, M.: Peroxy radicals in the summer free troposphere: seasonality and potential for heterogeneous loss, Atmos. Chem. Phys., 9, 1989-2006, doi:10.5194/acp-9-1989-2009, 2009.

Parrish, D. D., Allen, D. T., Bates, T. S., Estes, M., Fehsenfeld, F. C., Feingold, G., Ferrare, R., Hardesty, R. M., Meagher, J. F., Nielsen-Gammon, J. W., Pierce, R. B., Ryerson, T. B., Seinfeld, J. H., and Williams, E. J.: Overview of the Second Texas Air Quality Study (TexAQS II) and the Gulf of Mexico Atmospheric Composition and Climate Study (GoMACCS), J. Geophys. Res., 114, D00F13, doi:10.1029/2009JD011842, 2009.

Reichert, L., Andrés-Hernández, M. D., Stöbener, D., Burkert, J., and Burrows, J. P.: Investigation of the effect of water complexes in the determination of peroxy radical ambient concentrations: implications for the atmosphere, J. Geophys. Res., 108, 4017, doi:10.1029/2002JD002152, 2003.

Ryerson, T. B., Williams, E. J., and Fehsenfeld, F. C.: An efficient photolysis system for fast-response $\mathrm{NO}_{2}$ measurements, J. Geophys. Res., 105, 26447-26461, 2000.

Ryerson, T. B., Trainer, M., Angevine, W. M., Brock, C. A., Dissly, R. W., Fehsenfeld, F. C., Frost, G. J., Goldan, P. D., Holloway, J. S., Hübler, G., Jakoubek, R. O., Kuster, W. C., Neuman, J. A., Nicks, D. K., Parrish, D. D., Roberts, J. M., Sueper, D. T., Atlas, E. L., Donnelly, S. G., Flocke, F., Fried, A., Potter, W. T., Schauffler, S., Stroud, V., Weinheimer, A. J., Wert, B. P., Wiedinmyer, C., Alvarez, R. J., Banta, R. M., Darby, L. S., and Senff, C. J.: Effect of petrochemical industrial emissions of reactive alkenes and $\mathrm{NO}_{\mathrm{x}}$ on tropospheric ozone formation in Houston, Texas, J. Geophys. Res., 108, 4249, doi:10.1029/2002JD003070, 2003.

Salisbury, G., Monks, P. S., Bauguitte, S., Bandy, B. J., and Penkett, S. A.: A seasonal comparison of the ozone photochemistry in clean and polluted air masses at Mace Head, Ireland, J. Atmos. Chem., 41, 163-187, 2002.

Slusher, D. L., Huey, L. G., Tanner, D. J., Flocke, F. M., and Roberts, J. M.: A thermal dissociation-chemical ionization mass spectrometry (TD-CIMS) technique for the simultaneous measurement of peroxyacyl nitrates and dinitrogen pentoxide, J. Geophys. Res., 109, D19315, doi:10.1029/2004JD004670, 2004.

Sommariva, R., Haggerstone, A.-L., Carpenter, L. J., Carslaw, N., Creasey, D. J., Heard, D. E., Lee, J. D., Lewis, A. C., Pilling, M. J., and Zádor, J.: $\mathrm{OH}$ and $\mathrm{HO}_{2}$ chemistry in clean marine air during SOAPEX-2, Atmos. Chem. Phys., 4, 839-856, doi:10.5194/acp-4-839-2004, 2004.

Sommariva, R., Bloss, W. J., Brough, N., Carslaw, N., Flynn, M., Haggerstone, A.-L., Heard, D. E., Hopkins, J. R., Lee, J. 
D., Lewis, A. C., McFiggans, G., Monks, P. S., Penkett, S. A., Pilling, M. J., Plane, J. M. C., Read, K. A., Saiz-Lopez, A., Rickard, A. R., and Williams, P. I.: $\mathrm{OH}$ and $\mathrm{HO}_{2}$ chemistry during NAMBLEX: roles of oxygenates, halogen oxides and heterogeneous uptake, Atmos. Chem. Phys., 6, 1135-1153, doi:10.5194/acp-6-1135-2006, 2006.

Sommariva, R., Osthoff, H. D., Brown, S. S., Bates, T. S., Baynard, T., Coffman, D., de Gouw, J. A., Goldan, P. D., Kuster, W. C., Lerner, B. M., Stark, H., Warneke, C., Williams, E. J., Fehsenfeld, F. C., Ravishankara, A. R., and Trainer, M.: Radicals in the marine boundary layer during NEAQS 2004: a model study of day-time and night-time sources and sinks, Atmos. Chem. Phys., 9, 3075-3093, doi:10.5194/acp-9-3075-2009, 2009.

Stark, H., Lerner, B. M., Schmitt, R., Jakoubek, R., Williams, E. J., Ryerson, T. B., Sueper, D. T., Parrish, D. D., and Fehsenfeld, F. C.: Atmospheric in situ measurement of nitrate radical $\left(\mathrm{NO}_{3}\right)$ and other photolysis rates using spectroradiometry and filter radiometry, J. Geophys. Res., 112, D10S04, doi:10.1029/2006JD007578, 2007.

Tucker, S. C., Banta, R. M., Langford, A. O., Senff, C. J., Brewer, W. A., Williams, E. J., Lerner, B. M., Osthoff, H., and Hardesty, R. M.: Relationships of coastal nocturnal boundary layer winds and turbulence to Houston ozone concentrations during TexAQS 2006, J. Geophys. Res., 115, D10304, doi:10.1029/2009JD013169, 2010.
Warneke, C., Kato, S., de Gouw, J. A., Goldan, P. D., Kuster, W. C., Shao, M., Lovejoy, E. R., Fall, R., and Fehsenfeld, F. C.: Online volatile organic compound measurements using a newly developed proton-transfer ion-trap mass spectrometry instrument during New England Air Quality Study-Intercontinental Transport and Chemical Transformation 2004: performance, intercomparison, and compound identification, Environ. Sci. Technol., 39, 5390-5397, 2005.

Wood, E. C., Herndon, S. C., Onasch, T. B., Kroll, J. H., Canagaratna, M. R., Kolb, C. E., Worsnop, D. R., Neuman, J. A., Seila, R., Zavala, M., and Knighton, W. B.: A case study of ozone production, nitrogen oxides, and the radical budget in Mexico City, Atmos. Chem. Phys., 9, 2499-2516, doi:10.5194/acp-9-2499-2009, 2009. 